\title{
APPLICATION OF TECHNOLOGY ACCEPTANCE MODEL (TAM) IN FINTECH SERVICES
}

\author{
Arun Khatri' ${ }^{1}$, Nakul Gupta ${ }^{2}$, Anupama Parashar ${ }^{3}$ \\ ${ }^{1}$ Fellow- MDI Gurgaon, Haryana, India \\ ${ }^{2,3}$ Professor, MDI Gurgaon, Haryana, India
}

\begin{abstract}
Purpose - Financial Technologies (FinTech) is emerging as the core of digital innovation in the finance sector with promising technology and infrastructure. FinTech organizations are driven by data-finance, commodities, currencies, investment, payment systems, trading, exchange markets, regulation, consultancy services, banking, transaction settlement, financial intermediaries, and corporate governance. The purpose of this paper is to understand the consumer behavioural intentions in using Fintech Service, basis on the TAM, integrating brand and service trust to understand the influence on behavioural intention.
\end{abstract}

Approach - To understand the consumer behavioural intentions in using Fintech Service, this study basis on the TAM, integrating brand and service trust to understand the influence on behavioural intention. By using convenience sampling, 220 consumers' samples were collected. The results showed: Brand and service trust has a significantly positive effect on attitudes toward using Fintech Service. Perceived usefulness has a significantly positive effect on attitudes toward using. Perceived ease of use has a significantly positive effect on attitudes toward using. Attitudes toward on using have a significantly positive effect on behavioural intention to use. The use of latest ICT technologies lightens up the finance operations and services to exponential levels. The study tests the model in adoption of technology with innovation, and other adoption issues. The paper also presents a review of academic journals, literature, and assess the adoption of technology in the fintech revolution.

Findings - This finding reveals the importance of understanding the behavioural intention toward using Fintech Service. First of all, the exploratory factor analysis for consumer behaviour showed that the acceptance of new technology 5 domains (brand and service trust, perceived usefulness, perceived ease of use, attitude toward using, and behavioural intentions to use) This shall be of significant interest to researchers, professionals, academicians, and practitioners.

Key words: Fintech Service, Technology Acceptance Model, Theory of Reasoned Action, Brand, and service trust., Technology Adoption, Digital Payment 
Cite this Article: Arun Khatri, Nakul Gupta and Anupama Parashar, Application of Technology Acceptance Model (TAM) in Fintech Services, International Journal of Management, 11(12), 2020, pp 3520-3548.

https://iaeme.com/Home/issue/IJM?Volume $=11 \&$ Issue $=12$

\section{INTRODUCTION}

Fintech is a service sector which uses mobile-centred IT technology to enhance the efficiency of the financial system. As terminology, it is a mix of "finance" and "technology", and collectively refers to industrial changes forged from the convergence of tangent of financial services and Information Technology. For practitioners, it refers to the phenomenon where a non-financial business uses innovative technology to provide services, such as remittance, payment and settlement, and investment, without working with a financial company. According to the National Digital Research Centre in Dublin, Ireland, defines financial technology as "innovation in financial services", adding that "the term has started to be used for broader applications of technology in the space - to front-end consumer products, to new entrants competing with existing players, and even to new paradigms such as Bitcoin”. Alt, and Puschmann (2012) indicated that Fintech refers to new solutions which demonstrate an incremental or radical / disruptive innovation development of applications, processes, products or business models in the financial services industry. These solutions can be divided in five areas.

1. The banking or insurance sector are distinguished as potential business sectors. Solutions for the insurance industry are often more specifically named "InsurTech".

2. The solutions differ with regard to their supported business processes such as financial information, payments (such as mobile payment), investments, financing, advisory and crossprocess support.

3. The targeted customer segment distinguishes between retail, private and corporate banking as well as life and non-life insurance.

4. The interaction form can either be business-to-business (B2B), business-to-consumer (B2C) or consumer-to-consumer (C2C).

5. The solutions vary with regard to their market position.

Major Indian examples are Paytm, freecharge, phone-pe, payzapp, jiomoney, etc. 'FinTech' is a buzzword which originates and combines the words "financial" and "technology" and describes in general the connection of state of the art and, mainly, Internet-related technologies with established business activities of the financial services sector like money lending, transaction banking, funds transfer, e wallets etc. FinTech points to innovators and disruptors in the financial sector that make use of the availability of global communication, particularly via the Internet and computerized information processing. Emerging innovative companies have new business models that promise much more capability, flexibility, security, efficiency, and opportunities than conventional financial services (Lee 2015a). The innovator can be either a start-up (payU), an established technology company (payzapp- HDFC Bank), or an established service provider (like jiomoney). Based on Christensen's (1997) categorization of innovations, Lee (2015) differentiates between "sustaining FinTech', i.e., established financial services providers that try to protect their market position by the use of information technologies, and "disruptive FinTech", i.e., new companies and start-ups that challenge established providers by offering new products and services. Zavolokina et al. (2016) provide an interesting article on how differently the term "FinTech" is utilised and defined by various authors and institutions. In the past, information technology has often only been viewed as a tool in the financial industries context. Now, FinTech start-ups or established IT companies 
entering the financial domain find ground in the financial sector and capture customers that traditionally have been served by established financial organizations.

Why these once loyal customers are moving away, there are several reasons for this to happen:

The novel FinTech companies usually offer new products, services or solutions which satisfy customers' demands that have previously not or not sufficiently been addressed by the concerned financial service providers. One example is the postpaid limit offered by Indian startup unicorm 'paytm' to its users, which allows them to sped even without having actual money in their digital account. It's much like providing micro loans with just a few swipes at the mobile app. The big digital marketplaces like amazon and Walmart owned flipkart are also providing pay later facilities to the purchasers on their platforms, another form of micro lending. Market Invoice, for example, offers small- and medium-sized companies the possibility of selling their invoices in order to attain higher working capital by not being dependent anymore on the final payment of invoices (Lee 2015).

Companies with an IT background are relatively better suited to provide services in a highly innovative environment due to their digital capability and digital strategy, which allows them to act at the speed of light. Because changes and developments in the domain of communication and information technologies can be very quick and dynamic, companies in this field need to be agile and innovative.

As a result, the efficient IT companies often have a culture that is entirely different from established financial service providers. They are agile and innovative and flexible enough to set these established players under pressure or threat for their market share. FinTech companies usually concentrate on affordable and cost-efficient Internet-based business models in order to disrupt the market share of established financial services providers. Some of the experts in the field even believe that one day banks may only be utilized for deposits while everything else will be done by use of FinTech company services (Hemmadi 2015). King (2014) argued that founders of FinTech companies are often former bank employees who have been relieved of their jobs in the aftermath of the 2008 crisis. They possess practice the relevant expertise as well as the knowledge and have successfully managed to connect financial services with the novel emerging technologies to launch innovative companies and/or create new business models. Such experts are usually specialized in specific tasks within, for example, a bank. Thus, they are capable to create point solutions for services which are only small parts of the whole range of services of big financial service providers (King 2014). As a result, they can concentrate on optimizing these offered services. Dapp (2014) emphasized that FinTechs usually do not evolve from the traditional financial sector but have a technology background. The trend towards the successful FinTechs seems to be kept up as the development and improvement of mobile devices, big data analysis as well as cloud processing and data storage continues and new possibilities of simplification, adaptability, and individualization evolve (Dapp 2014). In summary, FinTech companies, i.e., both start-ups and established IT companies entering the financial domain, evolve at the intersection or tangent of information and communication technology and finance. They focus on business model innovations and new solutions for existing challenges in the financial sector.

Differentiation In the early $21^{\text {st }}$ century, the term "e-Finance" evolved for the use of information and communication technologies in the financial industry, before the terms "Digital Finance" and "FinTech" were introduced. The definition of the term "e-Finance" differs between authors and reveals different emphases. Petzel (2005) stated that authors start from different definitions of "electronic" and "finance" and, thus, end up with different definitions of e-Finance. Here, "finance" can embrace products, services, and/or institutions of the financial sector. There exist fundamental differences among authors concerning the definition of "electronic". While some use a relative broad definition and include all electronic 
communication and information processing (Allen et al. 2002), others only focus on the Internet as the electronic technology providing the fundament of e-Finance (Zask 2001). There are differences in how terms are set into relation with each other. As far as the relation of the Internet and financial products, the standardization of financial products is in focus, while regarding the financial institutions a much stronger emphasis on competition and collaborations between institutions is found. When focusing on information and communication technologies regarding the financial markets and respective institutions, e-Finance is seen as the disintermediation and re-intermediation between these instances (Petzel 2005). This fact bridges to today's understanding of FinTechs because these are enablers for disintermediation and re-intermediation of financial services and products through innovative technologies and solutions. Frequently and usually, the two terms Digital Finance and e-Finance are used as quasi-synonyms (Gattenio 2002). Basically, all three terms, i.e., Digital Finance, e-Finance, and FinTech, describe the processes of change in the financial sector through the introduction and use of information and communication technology. The term "e-Finance"' is frequently utilized in the context of the early beginning of companies starting to use information and communication technology in the financial sector; while the term "Digital Finance" is used for the widespread digitalization of the financial sector in the prior stages to till date. The term "FinTech" puts more emphasis on technological innovations and technological development diffused by the new organisations. Most FinTech companies have their origins not in the financial sector but are IT companies that create new solutions for challenges and tasks of the financial industry.

\subsection{Research Gap}

The literature shows the significant work in the domains of financial technology or Fintech and the testing of TAM model separately. No paper till now has focused on the Technology Adoption Model on the Fintech sector in Indian market and tested the theory in the Fintech sector. This paper contributes the testing of on the Fintech sector. Further this research also put light on the different dimensions of emerging technology along with its centricity in the Fintech sector. This paper also put together the different concepts and evolution on the Fintech sector. The integration of these concepts and an empirical testing will help the scholars to understand the acceptance of technology in the Fintech sector and will help further in the future research.

Research Objective: To study the adoption of technology in the financial sector giving rise to the Fintech phenomenon.

\subsection{Flow of Paper}

The flow of this paper is as follows:

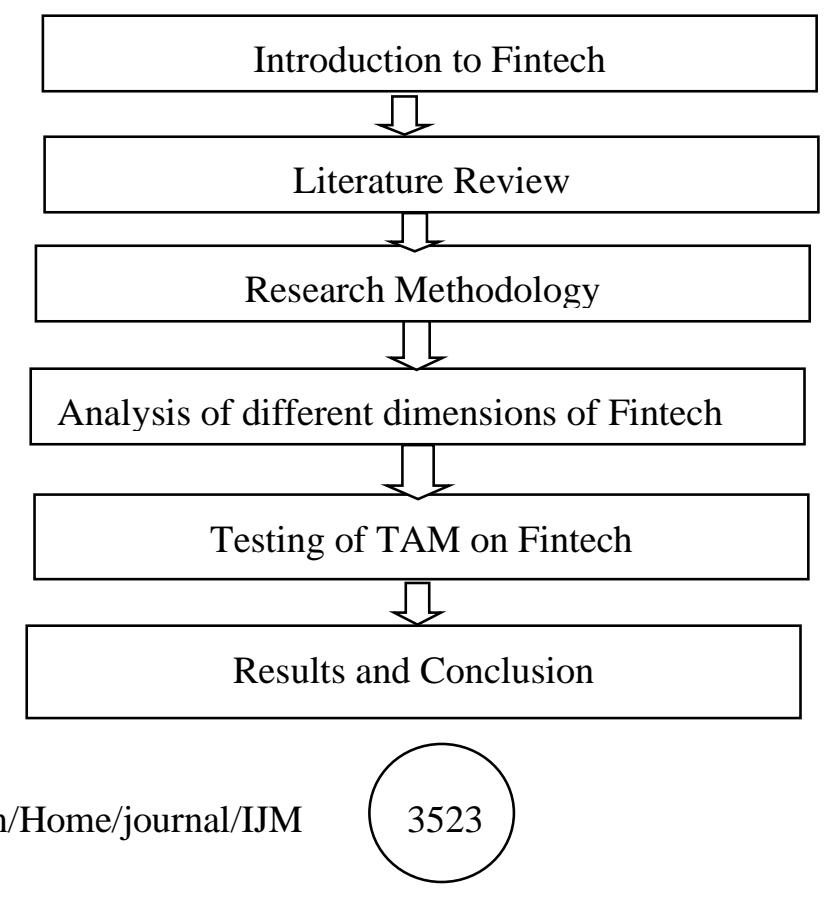




\subsection{Research Questions}

RQ1. Brand and service trust has a significant positive effect on a consumer's attitude toward using Fintech Service

RQ2. Perceived usefulness will have a significant positive effect on a consumer's attitudes toward using Fintech Service

RQ3. Perceived ease of use will have a significant positive effect on a consumer's attitudes toward using Fintech Service

RQ4. Consumer's attitude toward using Fintech Service has a significant positive effect on behavioural intention to use Fintech Service

"The growing deal sizes, higher levels of M\&A activity and the geographic spread of deals all highlight the increasing maturation of the fintech sector on a global scale," said Ian Pollari, Global Co-Lead, KPMG Fintech. "Fintech start-ups in markets as diverse as Germany and Brazil are attracting larger and later stage rounds, while the more established fintech leaders in the US, UK and Asia are making their own investments and acquisitions in order to expand their product and geographic reach."

\section{Key Highlights}

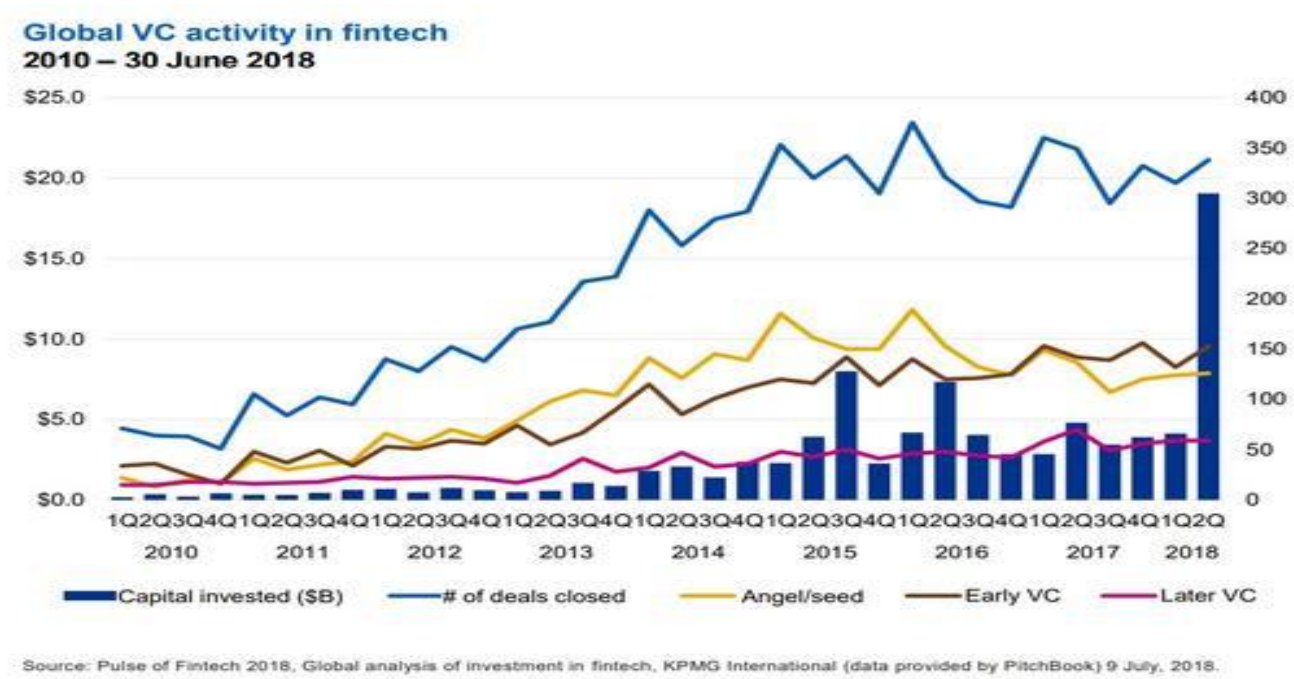

Figure 1

"Beyond new Fintech-fueled business models, the increasing regulatory and legal obligations emanating from PSD2, GDPR and other regulations are impacting both established players and emerging FinTechs," said Anton Ruddenklau, Global Co-Lead, KPMG Fintech.

\section{LITERATURE REVIEW}

The methodology used for the selection and preparation of this paper is presented in Figure 1. The SLR blueprint is broadly classified in to:
i)Research Context
and
ii) Research Area

The research context covers first, current research by providing information by providing information in terms of methods, application, results, strength, and limitations using different research articles. Two types of research were examined, namely, literature reviews and empirical studies. The selected databases are EBSCO, Emerald, Elsevier, ProQuest, Scopus and Google Scholar digital databases with linear and cross searches. Secondly, it covers the future 
research and directions highlighting the direction of the research. The research area of this study is targeted to banking and fintech industry.

Inclusion Criteria: The following inclusion criteria (IC) is utilised to select the literatures to be included in the review:

IC 1: The keywords used are: "big data", "big data analytics", "technology diffusion", "financial technology", "fintech". The operators used as syntax are OR and AND. The AND operator signifies that both keywords must be present in the search queries and OR means that at least one keyword must be present in the query.

IC 2: Studies published before December 31, 2020

IC 3: Studies published in English

IC 4: Studies limited to document type of journal articles

IC 5: Include abstract-based studies and IC 6: Include full-text-based studies

Exclusion Area: The exclusion criteria (EC) used to filter out the literatures are:

EC 1: Eliminate duplicate studies with matching title and /or Digital Object Identifier, doi.

EC 2: Eliminate the studies based on quality evaluation

Digital Database: The digital databases utilised to collect the data for the review of papers are i) IEEE ii) Emerald iii) Elsevier iv) ProQuest v) Springer vi) Google Scholar

Review Protocol Development: Google Scholar was first considered to extract data from these digital databases because: i) there is an extensive amount of studies available in context with our topic that are indexed, ii) it is the leading digital literature database which includes peer reviewed papers, iii) it has extensive scientific and inter disciplinary information. EBSCO, Emerald, Elsevier, ProQuest and Scopus were also reviewed for the papers.

Review Protocol Evaluation: To support the criteria to include, exclude, and to select the research data, it is important to examine and evaluate the quality of research studies. The purpose of the quality assessment is to ensure that the results of the study are suitable and unbiased. The various stages for data selection are shown in Figure 2 in a sequential manner. Each of the stage shown in the figure is executed with the accompanying IC, inclusion criteria and EC.

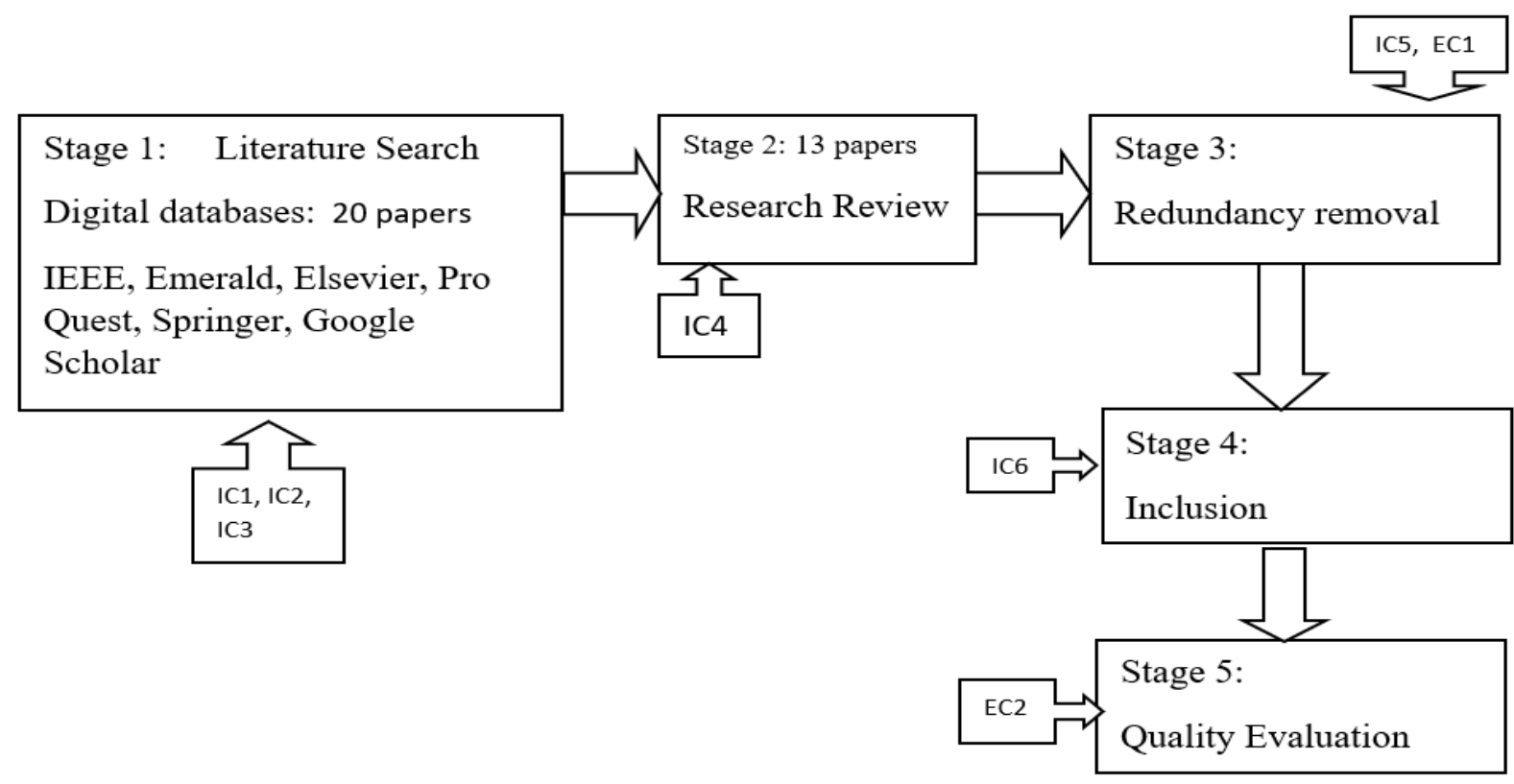

Figure 2 Data selection stages (Source: Compilation by authors) 
According to the National Digital Research Centre in Dublin, Ireland, defines financial technology as "innovation in financial services", adding that "the term has started to be used for broader applications of technology in the space - to front-end consumer products, to new entrants competing with existing players, and even to new paradigms such as Bitcoin". Alt, and Puschmann (2012) indicated that Fintech refers to new solutions which demonstrate an incremental or radical / disruptive innovation development of applications, processes, products or business models in the financial services industry. These solutions can be divided in five areas.

1. The banking or insurance sector are distinguished as potential business sectors. Solutions for the insurance industry are often more specifically named "InsurTech".

2. The solutions differ with regards to their supported business processes such as financial information, payments (such as mobile payment), investments, financing, advisory and crossprocess support.

3. The targeted customer segment distinguishes between retail, private and corporate banking as well as life and non-life insurance.

4. The interaction form can either be business-to-business (B2B), business-to-consumer (B2C) or consumer-to-consumer (C2C).

5. The solutions vary regarding their market position.

Table 1

\begin{tabular}{|c|c|c|c|c|}
\hline Sector & Business process & Customer segment & $\begin{array}{c}\text { Interaction } \\
\text { form }\end{array}$ & Market position \\
\hline $\begin{array}{l}\square \text { Bank } \\
\square \text { Insurer }\end{array}$ & $\begin{array}{l}\square \text { Payments/Investments } \\
\square \text { Financing Insurance } \\
\square \text { Advisory } \\
\square \text { Big data analytics and } \\
\text { predictive modeling } \\
\square \text { Security }\end{array}$ & $\begin{array}{l}\square \text { Retail banking } \\
\square \text { Corporate banking } \\
\square \text { Private banking } \\
\square \text { Life/ Non-life } \\
\text { insurance }\end{array}$ & $\begin{array}{l}\square \mathrm{C} 2 \mathrm{C} \\
\square \mathrm{B} 2 \mathrm{C} \\
\square \mathrm{B} 2 \mathrm{~B}\end{array}$ & $\begin{array}{l}\square \text { Bank/insurer } \\
\square \text { Non-bank/insurer - } \\
\text { bank/insurer- } \\
\text { cooperation } \\
\square \text { Non-bank/insurer - } \\
\text { bank/insurer- } \\
\text { competition }\end{array}$ \\
\hline
\end{tabular}

\section{RESEARCH METHODOLOGY}

Research Design Positivism approach in term of descriptive research will be adopted in this research to study the relationship between the perceived usefulness and Technology acceptance. Quantitative study is carried out for this study for the purpose of summarizing and generalizing the hypotheses tested that derived from the theory. Primary data is collected in this study because of the need to study the relationship among perceived usefulness and adoption.

Sample Population: Fintech users through mobile applications and other web applications. Sample Size: 220

Sample unit: Individual fintech users

\section{Hypothesis}

As a result of the research questions, the following set of hypotheses were derived:

H1: Brand and service trust has a significant positive effect on a consumer's attitude toward using Fintech Service

H2: Perceived usefulness will have a significant positive effect on a consumer's attitudes toward using Fintech Service. 
H3: Perceived ease of use will have a significant positive effect on a consumer's attitudes toward using Fintech Service

H4: Consumer's attitude toward using Fintech Service has a significant positive effect on behavioural intention to use Fintech Service

\section{Questionnaire Design}

The questionnaire was divided into two sections, namely Section A and Section B. Section A include the variables that appear in the demographic profiles. Section B of the questionnaire consists of all the variables that measure the tested constructs were listed in. All the tested constructs were measured by 5-point Likert Scale (1-strongly disagree to 5- strongly agree).

\section{Sampling Design}

The study focuses on the fintech users in the Delhi/ NCR region, India. Due to the inability of compiling a sampling frame, non-probability sampling was adopted in this research. Judgmental sampling technique was adopted as non-probability sampling because the technique itself allows the researchers to consciously select respondents in the study (Burn and Bush, 2003). Sufficient sample size was required in this research for the purpose of minimizing the sampling error of the non-probability sampling and enhancing the precision of the sampling outcome. Therefore, a total of 150 respondents were set as the sample size in this research. A pilot study was conducted in advance to ensure that the questionnaire is error free and easy to understand. A full scale of self-administered survey was launched immediate after receiving the feedbacks from the pilot test. Online survey method including emailed surveys and monkeysurvey.com and google forms were used to ensure the confidentiality and nonobligation aspects of participating in the survey. The voluntary nature of the participation was explained as well as being indicated in the survey questionnaire. Employees were invited to complete an anonymous survey questionnaire that took approximately 15-20 minutes of their time to complete. A total of 250 sets of questionnaires were distributed and 220 questionnaires were collected.

The statistical Program SPSS version 22.0 is used in this study to perform the statistical analysis. Descriptive analysis, scale measurement (reliability and validity tests) would be carried out in the data analysis.

Reliability Test: Reliability is referred to the degree in which the scale measurements are free from errors and yields consistent result from the study (Bajpai, 2011). According to Bernard (2000), there are three types of reliability: stability reliability, representative reliability and equivalence reliability. Cronbach's alpha was utilized in this research to evaluate the reliability of the scale measurement.

\section{FINANCE AND TECHNOLOGY: FINTECH}

This paper argues that FinTech should be understood to be much broader in at least two ways than as currently defined. The embrace of this broader conceptualization could be a sufficient condition to the proposition that big data analytics provides the central insight into FinTech. First, advances in information, communications and computer technologies (ICT) underlie most innovation in financial markets, starting centuries ago and until now. Second, financial innovation based on technological advances is hardly new, indeed, it has been driving financial market development for much of history. FinTech innovation has increased at high speed over the past three decades with the advent of financial engineering, 12 a mathematically-based subdiscipline that largely focuses on arbitrage, derivatives and innovations in financial products, instrumentation and strategies.13 Today, FinTech assumes many forms with impact in financial sectors well beyond financial engineering. This paper analyzes some defining moments 
imposed by FinTech throughout financial history to induce a regulatory model useful in research, instruction, and public policy development. A FinTech taxonomy is advanced that should enable prompt reaction - a regulatory paradigm for remediation of FinTech malfunctions.14 This is a readiness paradigm enabling financial regulators and private party victims to intercede quickly

When FinTech fails. A concise history of select FinTech watersheds is reviewed to illustrate both successful and failed FinTech regulatory approaches, and the role of digitizing huge historical databases to become FinTech big data.

Anticipatory FinTech Regulation should be more broadly understood to target all major sectors of the financial industry as traditionally articulated, including,

(1) investment banking; (2) startup finance; (3) securities, derivatives and commodities;

(4) brokerage, dealers and financial intermediaries; (5) investment advice;

(6) corporate disclosure, investor relations and corporate democracy;

(7) new forms of money and currency transactions; and

(8) the monitoring and enforcement of money flows particularly Anti-Money Laundering controls (AML).

Many FinTechs appeal to the cyber-libertarian goal to achieve successful separation from societal control irrespective of the physical location of individuals or organizations. Stealth initial deployment, a chronic attribute of many FinTech, is examined as FinTech operations migrate to rogue havens making FinTech stubbornly resistant to revealing forensic quality evidence. Consider that many FinTechs employ traditional supply chain elements of communications, standardized documentary instrumentation, trading platforms and exchange markets. FinTechs generally challenge the (value added) role of intermediaries.

Anticipatory FinTech Regulation is developed here as a big data approach to FinTech that balances three key FinTech influences:

(1) incentivizing FinTech innovation,

(2) enhancing market failure forensics and

(3) developing public policy resolutions to a broad array of FinTech challenges.

FinTech presents THE grand challenges in financial regulation and financial security today. Here we argue, big data analysis provides a balanced solution.

One of the most popular crypto-currency case, Bitcoin, the innovation has not yet achieved wide adoption in the global financial market till now. The main problem with the Bitcoin to achieve wide market acceptance is that the innovation is not backed by many governments and not recognized as a legal tender. The central banks of many countries around the world advise the users to be aware of the risks associated with Bitcoin usage because Bitcoin digital wallets are vulnerable to theft and loss. The competing mining protocol standards, the lack of collaborative solutions and the problems of insecure computer and internet infrastructure have hindered Bitcoin to achieve global adoption.

The development of financial technology, such as electronic, digital, and Fintech Service has resulted in an ever increasing advancement in service productivity, which continues to challenge and cater to the attitudes of consumers who are accepting of new technology products to gain market opportunities. In response to the new ideas involving new technology applications with great market potential, Fintech Service have become the focus of new technological applications (Kim, Park, Choi, \& Yeon, 2015). Fishbein \& Ajzen (1975) proposed the Theory of Reasoned Action (TRA), and has been considered as an excellent reference model in the field of prediction or explanation of personal behaviour (Figure 1) Such intention model explores the relationship between attitude and behavioural intention is the 
Technology Acceptance Model (TAM). The TAM assumes that the key determinant of behavioural intentions is depends on a person's beliefs about their own ability to use a piece of technology and their subjective evaluation of the usefulness of that technology (Bruner \& Kumar, 2005; Hernandez, Jimenez, \& Martin, 2009; Morgan \& Veloutsou, 2011; Palvia, 2009; Pavlou, Liang, \& Xue, 2007). Scholars seldom use the consumer's point of view to combine with the intention model to discuss factors that affected behavioural intention to use a new technology in past researches (Legris, Ingham, \& Collerette, 2003; Szajna, 1996). Because the Fintech Service is an innovative high-tech product, using Fintech Service as a study subject and TAM to investigate consumers who use Fintech Service or have the potential intention to use Fintech Service to explore whether consumer attitudes concerning Fintech Service has significant effects on the behavioural intention to use Fintech Service is becoming an important issue. This study used brand and service trust as an antecedent for the control variable of attitude to discuss whether brand and service trust significantly affect consumer attitudes toward using Fintech Service and whether consumer attitudes toward using Fintech Service affect consumer behavioural intention to use Fintech Service

\subsection{FinTech's Big Promise}

Frustration with the status quo is an oft-cited impetus for FinTech. FinTech innovations are early always predicted to yield some efficiencies and useful opportunities, particularly in transaction processing, financial analysis, and the development of alternative investment vehicles or business methods. Efficiencies are generally predicted to be the product of disruptive disintermediation, the reduction of transaction processing, advice or facilitation by agents.23 The deployment of computerized telecommunications usually permits FinTech entrepreneurs to claim faster, democratized and more accurate operations. Existing market failure or sluggishness are also targeted by FinTechs. In other situations, FinTech leads to reintermediation. Alternatively, some regulatory-oriented FinTechs, particularly those inspired by expanding existing data to become big data, amplify transparency, attenuate market failure or produce positive externalities for society. Recognition of the alternating causality between FinTech and big data analytics suggests FinTech is a compelling domain for big data analytics. Stated alternatively, as an organizing principle, a big data analytics lens provides a unique approach, fundamental to the development, understanding and regulation of FinTech not well recognized in existing literature.

\subsection{FinTech's Delivered Effects}

It is hardly surprising that some FinTech mechanisms externalize their design flaws, their opacity and obscurity, or their malfunctioning to contribute to various types of market failure. Most of the major FinTech watersheds in the 20th and 21st Century history of securities and commodities regulation, banking regulation and insurance teach that FinTech almost always deserves a wary eye. Too often, FinTech is arguably intended to skirt regulation or avoid regulatory costs. It is hardly surprising that FinTech entrepreneurs are initially seldom very aggressive to bolster their emerging industry's reputation by seeking reasonable regulation. Many forms of FinTech start with stealth operations that trigger abuse and side effects cautilised by their too often incalculable and uncertain risks. In most instances, big data can play a key role in resolving FinTechs unintended consequences. Furthermore, FinTech's often decentralized architecture (P2P, distributed nodes, cloud storage) operates similar to other Internet services by defying jurisdiction of tougher and savvy regulators. This creates a classic "race to the bottom" as lax regulatory hosting venues attract FinTechs. The result is a heightened systemic risk for most all markets for financial services.24 FinTech nearly always imposes regulatory challenges as a result of these substantial influences. Therefore, to avoid the harmful societal externalities of FinTechs, an anticipatory FinTech regulatory dimension is 
advocated here using provisional ontologies. This model requires a big data marshalling model and urges adoption of a big data dimension on FinTech development and regulation. Both champions of FinTech innovation as well as FinTech skeptics and financial market regulators can benefit from the development here of a generalized model deploying big data and analytical methods. Not surprisingly, some FinTechs are creations of government. These are largely transparency regimes using standardized disclosure, such as EDGAR, xBRL, ISO 20022, or the Dodd-Frank swap disclosures.25 Still, FinTechs often develop long before understanding by regulators is achieved or regulators can develop effective regulatory balance.26 Delays between

FinTech development/deployment and effective public policy response development/implementation constitutes a form of regulatory lag.

\subsection{Summarizing a FinTech Ontology}

FinTech is substantially new, its popular descriptions are largely established by promoters and adherents of a few recent FinTech trends: crowd-funding, blockchain and cryptocurrencies, and robo-advising. As with any popular theme attending a field's development, "what has been done lately" commandeers the most attention by attenuating almost all other context. By contrast, this paper runs counter by offering historical context of innovation in financial services permitting a different taxonomy: money and payments, contracts and financial claims structuring in instruments, intermediation and syndication, disclosure, standardization, analytics techniques - financial and creditworthiness analysis, and the embodiment of innovations in intellectual property. In addition, we adhere to the traditional U.S. visions of financial services subfields of commodities and foreign exchange, commercial banking, investment banking and insurance. As to the next big thing that may usher the transition from the fourth ICT era into some hypothetical fifth era, currently the most compelling candidate watershed factor is AI. If reliably useful, AI can be developed that significantly impacts many trenches of financial services, the fifth FinTech era may dawn.184 However, that time has not yet come despite some limited AI success in the fraud and intrusion detection components of a few FinTechs. AI is hugely complex and although many brilliant minds and powerful computer capabilities are diligently deployed to AI's success, AI progress must await resolution of its data interoperability problem. While the taxonomy developed here acknowledges AI could develop a long and promising ascension, FinTech still awaits any significant transformational impact from AI, despite repeated assurance from AI's adherents of it's transformative imminence. Any AI revolution to a fifth FinTech era seems more likely to mature in the medium term future.

\subsection{Ontology of FinTechs from a Chronological viewpoint}

A provisional chronology of FinTech from the pre-FinTech ancient/medieval era, through U.S. history in the 19th and 20th century, to the post-war modern era, and ultimately to the modern FinTech period provides an opportunity to trace FinTech's technological development history. This analysis also marks key transformative change points and their disruptive challenges to FinTech public policy.39 Other scholars have proposed typologies, some casting them as FinTech business models. For example, Lee and Shin argue that current and proposed FinTechs should be divided into six discrete business models:

(1) payments, (2) wealth management, (3) crowdfunding,

(4) lending, (5) capital markets, and (6) insurance.

They predict FinTech will face the greatest challenges in the areas of investment management, customer management, regulation, technology integration, security and privacy, and risk management. The Partial FinTech Chronology depicted in Figure I, illustrates the difficulty of taxonomy development, given an accelerated pace of technological change. 


\subsection{Four Eras of Fintech: Tracing FinTech through Four Eras}

After the pre-FinTech era of ancient through medieval times, we divide FinTech into three modern eras that follow three major technological watersheds: first, electrical analog telecommunications, second, computerized recordkeeping, and third, fusion of these first two into ICT deployed or under development in the current era. The impact of FinTech, developed throughout the 20th Century, is spurred significantly by innovations and ubiquity of telecommunications and computational power. FinTech's second stage, the first of the modern era, roughly tracks industrial capitalism. Much of FinTech innovation was based on analog electronic communications developed in the 19th century - telegraphy and telephony. These twin innovations spurred significant FinTechs by improving communications that have extended well into in the 20th century. Near instantaneous electronic communications made financial markets and services accessible from/to across the U.S. and around the world. Major financial markets 37 were enabled to more permanently coalesce into a few of the world's moret influential developing venues, including, New York, London, Frankfurt, Hong Kong, Tokyo, and others.38 FinTech's second modern era began to transition by the 1970s as computer recordkeeping finally invaded the "back office" of insurance, commercial and investment banking. Computerization also permitted statistical risk analyses, important in risk underwriting and financial analysis. This era also witnessed the development of electronic order processing, program trading, electronic corporate democracy, and electronic financial disclosure.

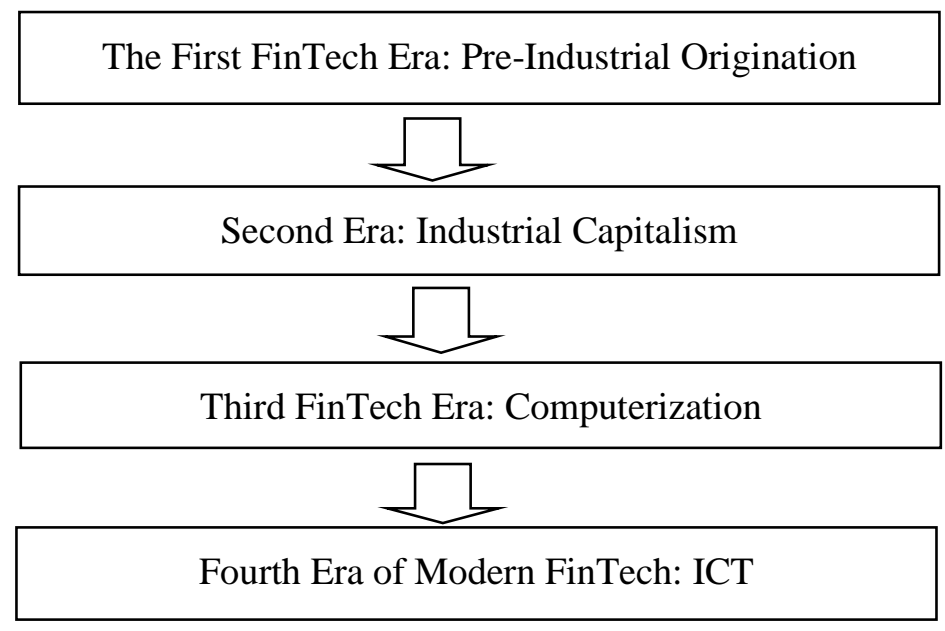

Figure 1 The four eras of Fintech

\subsubsection{The First FinTech Era: Pre-Industrial Origination}

From ancient times to the industrial revolution, financial technologies developed slowly, often spurred by conflict and in relation to religious activities. At the time of these FinTechs were introduction, each could produce big data for that time. Considering the difficulties in recording, storage, communicating and analyzing data using technologies of the era, FinTechs created what became big data of that time in history. Most FinTechs originally developed during this period persist in some form today and continue to be big data driven. Much of the ancient FinTech successes developed in ancient Greece and Rome, with the Crusades, and the rise of mercantilism also influential. Stabilization of the enduring FinTechs was guided by a few, large nation states, particularly imperialist nations of Western Europe which colonized the New World such as the Dutch, Italians, English, Spanish, Prussians and Portuguese. Financial services are the infrastructure for the development of trade and industrial-based commerce, the major growth of which developed in the first two millennia AD. Four enduring FinTech first principles were developed during this origination era, then were extended and refined from 
ancient times through the middle ages. Nearly all modern variations of financial services are established from these origination eras starting points:

\section{(1) Contract, (2) Money, (3) Intermediaries (4) Organized Exchange (auction) markets, and (5) Legitimation of Debt}

These five pillars are the bedrock institutions that support and expand into voluntary negotiated exchange under contract, evolution from barter to recognition of money as secure and standardized medium of exchange, physical security for financial assets and services by third parties, advanced quality control for recordkeeping, correspondent banking, syndication networks, and standardized (auction) market mechanisms.

\subsubsection{Second Era: Industrial Capitalism}

The second era is the first stage in the modern era, roughly tracking the industrial revolution through to the mid-20th century. Analog electronic telecommunications that developed in the 19 th century, telegraphy and telephony 68 were most influential. This disruption permitted near instantaneous electronic communication to and from centralized financial markets. Communication tied together geographically separated exchange markets and provided immediate visibility to supply, demand, completed transaction prices, and trading volume. At first, all these and other data derived there from were recorded by hand and, too often, haphazardly at best, most likely due to cost, delays, technical infeasibility, failures to embrace their social utility and a desire for opacity by some participants. However, advances in recordkeeping remove most of these limitations permitting the accumulation of this information into big data. This environment produced new financial services to accommodate higher volumes of speculative investment, permit entrepreneurs to gain better access to capital raising, and expand the pools of potential investors and opportunities. The democratization of investments also functioned to undermine banking as the solitary investment opportunity for many individual savers who could transition to become investors. Many new financial market participants gained access from/to geographically isolated areas. Major financial markets more permanently grew, yet coalesced, creating a somewhat geographically dispersed financial services infrastructure that magnifies the development of an integrated exchange market despite dispersed venues. This network eventually approximates a true national market system (NMS).

Following financial services were established from the second era:

\section{(1) Syndication (2) Financial Exchanges (3) Electronic funds transfer (EFT) (4) Regulation (5) Disclosure Regime \& its Intermediation}

\subsubsection{Third FinTech Era: Computerization}

The third FinTech era, the second era of modern times, herein is called the computerization era. The start of this era begins with the electronic computerization of financial records. For much of FinTech, this watershed was probably reached when Wall Street was forced by the avalanche of increased trading records retained on paper to automate recordkeeping in its "back office." Exchanges outgrew their collective character as agents of competing members and banded together into self-regulatory organizations (SRO) capable of metering, retaining, monitoring and supervising member activities based on their separate big data collections. The FinTech big data relationship among the major FinTech sectors defined here is becoming clearer: recordkeeping that populates big data accumulations, analytics, disclosure, regulation, institutions and trading strategies are inextricably linked in feedback loops. Big data drives analytics, analytics inspire models, models produce propositions, propositions inspire recommendations, recommendations imply actions, actions are manifest as innovations embodied as trading strategies, such innovations are often implemented as transactions, results 
are measured then monetized or deployed against activities of others, institutions are impacted by results, and institutions restart one or more of these cycles. Following financial services were established from the third era:

\section{(1) Automated clearing houses (ACH)}

\section{(3) Countertrade}

\section{(5) Analytics Techniques}

(7) Electronic Data Interchange

\section{(9) Financial Institutions}

\subsubsection{Fourth Era of Modern FinTech: ICT}

The fourth era of FinTech is upon us, starting roughly in the 1990s, persisting through today and most likely extending into the near to medium term.127 It is defined by the ubiquity of ICT - a fusion of computerization with rapid, high-throughput telecommunications of data, images, text and other data forms. Furthermore, at least four other technologies enable this ICT era: (1) well-connected, secure and reliable Internet, (2) trustworthy and economical cloud accessibility for posting and accessing large data sets, (3) robust private networks, and (4) interoperability based on highly functional ICT standards. Finally, some might assert that AI contributes significantly to the current ICT era, however, solid evidence of this as a key watershed remains inconclusive. Following financial services were established from the fourth era:

\section{(1) ICT enabled Payments (2) Toll Tags (3) Check Truncation (4) Electronic Payment Systems}

\section{TECHNOLOGY ADOPTION MODEL}

\section{Theory of Reasoned Action}

According to the theory of reasoned action (TRA) developed by Fishbein and Ajzen, the main determinant of an individual's behaviour is his/her intention, which is influenced jointly by the individual's attitude and the subjective norm. In TRA, attitude toward the behaviour is defined as "the individual's positive or negative feelings about performing a behaviour." That attitude is determined by assessing one's beliefs regarding the consequences arising from a behaviour and an evaluation of the desirability of those consequences. Subjective norm is defined as "an individual's perception of whether people important to the individual think the behaviour should be performed." The opinion of a referent is weighted by an individual's motivation to comply with the wishes of the referent. TRA has some limitations, including a significant risk of confounding attitudes and norms since attitudes can often be reframed as norms and vice versa. A second limitation is the assumption that when someone forms an intention to act, they will be free to act without limitation. In practice, constraints of ability, time, environment, organization, or unconscious habits will limit the freedom to act.

\section{Theory of Planned behaviour}

The theory of planned behaviour (TPB) developed by Ajzen, attempts to deal with these limits. The theory is another variant of TRA that takes into account the perceived behavioural control as a third determinant of an individual's behavioural intention to use a new system. In attempting to apply TPB (which, like TRA, is a generalized model), a decomposed TPB has 
also been examined in the IS literature which attempts to identify and model the specific antecedents to attitude, subjective norm, and perceived behavioural control relevant to IT use.

\section{The Technology Acceptance Model}

The Technology Acceptance Model (TAM), developed by Davis, is an adaptation of TRA. This model defines perceived ease of use and perceived usefulness as two determinants of attitude toward behavioural intention and usage. In this model, perceived ease of use is defined as "the degree to which a person believes that using the system will be free of effort'; perceived usefulness is defined as "the degree to which a person believes that use of the system will enhance his or her performance.'" Perceived ease of use, which also determines the perceived difficulty of use, represents the individual's perceived cost of using the system. The perceived usefulness of a system represents the individual's view of the benefits of using the system. These two variables are considered in terms of cost-benefit issues. Taylor and Todd suggest perceived usefulness, perceived ease of use, and compatibility as antecedents of attitude (largely consistent with TAM). In addition, they suggest that peer influence and superiors' influence are antecedents of subjective norm. Finally, they model self-efficacy, resource-facilitating conditions, and technology-facilitating conditions as determinants of perceived behavioural control. The theories examined so far have been enhanced in several ways from the basic uptake models from the 1960s to date. Considerable empirical research has been conducted in order to discover the factors influencing the adoption and diffusion patterns of innovation. Several other authors explore technology diffusion in different industries, and all conclude that there are generalizable constructs even as technologies diffuse.

Many scholars have focused on factors that affect the use of new technologies, including relative advantage, ease of use, compatibility, trial ability, visibility, result demonstrability, image, and voluntariness (Moore \& Benbasat. 1991; Svendsen, Johnsen, Sørensen, \& Vitters $\varnothing$. 2013). The perceived usefulness and perceived ease of use would affect the behaviour of using new technologies and would be affected by the external variables included individual characteristics, system characteristics, and organizational support (Igbaria, Guimaraes, \& Davis, 1995).

Technology Acceptance Model (TAM) Davis (1986) proposed Technology Acceptance Model (TAM) and used this model to discuss the effect of external variables on personal internal beliefs and attitudes. He stated that TAM also considered behavioural intentions were affected by personal attitudes toward using the information system. In order to explain and predict the user's behaviour of information technology more efficiently, Davis, Bagozzi, and Warshaw (1989) based on the Theory of Reasoned Action (TRA) to modify its theoretical model to fit the application of information systems context. Svendsen, Johnsen, Sørensen, and Vitters $\varnothing$ (2013) also advocated the use of two sets of variables (perceived usefulness, perceived ease of use) to explore the user's behaviour in accepting the information technology.

\subsection{TAM Literature}

This study collected the past relevant research literatures that affect the use of new technology factors and found that indeed there are many scholars adapted TAM as the main theoretical framework and developed many empirical bases. The following table illustrates the details. Table the relevant research of TAM Scholar 
Table 2

\begin{tabular}{|c|c|c|c|}
\hline Scholar & Year & $\begin{array}{l}\text { Theme of } \\
\text { Study }\end{array}$ & Conclusion / Finding \\
\hline $\begin{array}{l}\text { Eltayeb \& } \\
\text { Dawson }\end{array}$ & 2016 & $\begin{array}{l}\text { Personal } \\
\text { Cloud } \\
\text { Computing } \\
\text { (PCC) }\end{array}$ & $\begin{array}{l}\text { 1. Personal Cloud Computing (PCC) is a rapidly growing technology, } \\
\text { addressing the market demand of individual users for access to available and } \\
\text { reliable resources. } \\
\text { 2. Users decided to adopt PCC may be concerned about the ease of use, } \\
\text { usefulness, or security risks in the cloud. } \\
\text { 3. Negative attitudes toward using a technology have been found to } \\
\text { negatively impact the success of that technology. } \\
\text { 4. The results shows that in spite of the potential benefits of PCC, security } \\
\text { and privacy risks are deterring many users from moving towards PCC. }\end{array}$ \\
\hline $\begin{array}{l}\text { Cheung \& } \\
\text { Vogel }\end{array}$ & 2013 & e-learning & $\begin{array}{l}\text { 1. Used the technology acceptance model to explain the factors that } \\
\text { influence the acceptance of Google Applications for collaborative learning. } \\
2 \text {. According to the results, determinants of the technology acceptance model } \\
\text { are the major factors influencing the adoption of the technology. } \\
\text { 3. In addition, the subjective norm represented by peers is found to } \\
\text { significantly moderate the relationship between attitude and intention toward } \\
\text { the technology. }\end{array}$ \\
\hline $\begin{array}{l}\text { Yousafzai } \\
\text { et al. }\end{array}$ & 2010 & $\begin{array}{l}\text { Information } \\
\text { Technology }\end{array}$ & $\begin{array}{l}\text { 1. An objective of information technology (IT) research is to assess the value } \\
\text { of technology for users and to understand the factors that determine this } \\
\text { value in order to deploy IT resources better. } \\
\text { 2. This paper uses structural equation modeling to ascertain the extent to } \\
\text { which } 3 \text { popular models of users' behaviour - theory of reasoned action } \\
\text { (TRA), theory of planned behaviour (TPB), and technology acceptance } \\
\text { model (TAM) - are predictive of consumers' behaviour in the context of } \\
\text { Internet banking. } \\
3 \text {. The results indicate that TAM is superior to the other models and } \\
\text { highlights the importance of trust in understanding Internet banking } \\
\text { behaviour. }\end{array}$ \\
\hline Yu et al. & 2005 & $\begin{array}{l}\text { T- } \\
\text { Commerce }\end{array}$ & $\begin{array}{l}\text { 1. Seven factors were identified: perceived ease of use, perceived usefulness, } \\
\text { perceived enjoyment, trust, attitude, normative belief of family and friends, } \\
\text { and subjective norm. } \\
\text { 2. Perceived enjoyment is the most important factor affecting attitude and } \\
\text { behavioural intention toward t-commerce. }\end{array}$ \\
\hline $\begin{array}{l}\text { Gefen et } \\
\text { al. }\end{array}$ & 2003 & $\begin{array}{l}\text { Business to } \\
\text { Consumer } \\
\text { Internet- } \\
\text { based } \\
\text { services }\end{array}$ & $\begin{array}{l}\text { Examine the effect of social presence on consumer trust in e-services and } \\
\text { the relative importance of consumer trust in comparison with the widely } \\
\text { studied TAM beliefs. }\end{array}$ \\
\hline Chen et al. & 2002 & $\begin{array}{l}\text { On-line } \\
\text { Consumers }\end{array}$ & $\begin{array}{l}\text { Apply the TAM and IDT to examine consumer behaviour in the virtual store } \\
\text { context. }\end{array}$ \\
\hline $\begin{array}{l}\text { Moon \& } \\
\text { Kim }\end{array}$ & 2001 & $\begin{array}{l}\text { World- } \\
\text { Wide-Web } \\
\text { Context }\end{array}$ & $\begin{array}{l}\text { Used playfulness as an intrinsic motivation factor that reflects the user's } \\
\text { intrinsic belief in WWW acceptance. }\end{array}$ \\
\hline $\begin{array}{l}\text { Venkatesh } \\
\text { \& Davis }\end{array}$ & 2000 & $\begin{array}{l}\text { Four } \\
\text { Longitudinal } \\
\text { Field Studies }\end{array}$ & $\begin{array}{l}\text { 1. Based on Technology Acceptance Model (TAM), used the extended } \\
\text { model-TAM } 2 \text { and longitudinal data to test four different systems at four } \\
\text { organizations, two involving voluntary usage and two involving mandatory } \\
\text { usage. }\end{array}$ \\
\hline
\end{tabular}




\begin{tabular}{|l|l|l|l|}
\hline & & & $\begin{array}{l}\text { 2. Both social influence processes (subjective norm, voluntariness, and } \\
\text { image) and cognitive instrumental processes (job relevance, output quality, } \\
\text { result demonstrability, and perceived ease of use) significantly influenced } \\
\text { user acceptance. }\end{array}$ \\
\hline Szajna & 1996 & $\begin{array}{l}\text { Information } \\
\text { Systems }\end{array}$ & $\begin{array}{l}\text { The results confirmed that the TAM is a valuable tool for predicting } \\
\text { intentions to use an IS. }\end{array}$ \\
\hline $\begin{array}{l}\text { Igbaria et } \\
\text { al. }\end{array}$ & 1995 & $\begin{array}{l}\text { Microcompu } \\
\text { ter Usage }\end{array}$ & $\begin{array}{l}\text { 1. The tested conceptual model confirms the effects of individual, } \\
\text { organizational, and system characteristics on perceived ease of use and } \\
\text { perceived usefulness. } \\
\text { 2. The model also confirms the influence of perceived ease of use on } \\
\text { perceived usefulness, and the effects of perceived usefulness on perceived } \\
\text { usage and variety of use. } \\
\text { 3. Results confirm several previously proposed notions, including the effects } \\
\text { of individual, organizational, and system characteristics on ease of use and } \\
\text { usefulness. } \\
\text { 4. The influence of ease of use on usefulness, and the effects of perceived } \\
\text { usefulness on usage and variety of use. }\end{array}$ \\
\hline $\begin{array}{l}\text { Moore \& } \\
\text { Benbasat }\end{array}$ & 1991 & $\begin{array}{l}\text { Information } \\
\text { Technology } \\
\text { Innovation }\end{array}$ & $\begin{array}{l}\text { 1. Develop the scale to measure the perceptions of individual of adopting an } \\
\text { information technology innovation. } \\
\text { 2. 8 factors that affect the use of new technologies: relative advantage, ease } \\
\text { of use, compatibility, trial ability, visibility, result demonstrability, image, } \\
\text { and voluntariness }\end{array}$ \\
\hline $\begin{array}{l}\text { Davis et } \\
\text { al. }\end{array}$ & 1989 & $\begin{array}{l}\text { User } \\
\text { Acceptance } \\
\text { of Computer }\end{array}$ & $\begin{array}{l}\text { 1. Perceived usefulness strongly influenced peoples' intentions. } \\
\text { 2. Perceived ease of use had a small but significant effect on intentions as } \\
\text { well. } \\
\text { 3. Attitudes only partially mediated the effects of these beliefs on intentions. } \\
\text { 4. Subjective norms had no effect on intentions. }\end{array}$ \\
\hline
\end{tabular}

\subsection{TAM and Innovation}

In the innovation studies literature, Rogers used well-established theories in sociology, psychology, and communications to develop an approach to study the diffusion of innovations (Rogers, 1983, 1995, 2003). According to the study by Rogers (1983, 1995, 2003), the innovation development process comprises six stages: problem definition, research (basic and applied), development, commercialization, adoption and diffusion and consequences. Some of the pioneering works in the area innovation diffusion also include the concept of technology acceptance (Davis, 1989; Venkatesh and Davis, 2000; Venkatesh et al., 2003). The technology acceptance model (TAM) developed by Davis (1989) is the most widely known theoretical framework explaining the process of technology adoption and diffusion. According to the TAM Model, the main factors influencing user adoption in the marketplace are:

- Perceived ease of use (PEOU). The degree to which a person believes that using a particular system would be free from effort; and

- Perceived usefulness (PU). The degree to which a person believes that using a particular system would enhance his or her job performance.

TAM, based on the theory of reasoned action (TRA), has also been used to understand and predict the users' acceptance of technologies. From the technology management perspective, the model can be used to understand consumer behaviour, target market and help predict usage across different fields of technology-based innovations. The Unified Theory and Acceptance and Use of Technology (UTAUT) model is another important model that was developed and 
based on the TAM Model. UTAUT describes additional key constructs determining the behavioural intention: performance expectancy, effort expectancy, social influence and facilitating conditions (Venkatesh and Davis, 2000; Venkatesh et al., 2003; Wang and Wang, 2010). The diffusion theory often deals with the innovation process. The innovation process characteristically exhibits an S pattern. Schumpeter's long-wave theory explains the waves of economic development whereby the shift from existing business cycle to new one leads to the growth of industrializations. The Schumpeterian view of creative destruction emphasizes discontinuity of economic development. That is to say, the process of creative destruction brings about the economic growth of which the emergence of new product/process innovations does not grow out of the old ones but eliminates them (Schumpeter, 1939, 1967). Utterback and Abernathy (1975) articulate the innovation process as an S pattern. Vernon (1966)'s product life cycle (PLC) is a classical model explaining the development as a pattern of product substitution (the S-curve pattern). The phases along the PLC reflect innovation diffusion - the progress of product/process innovations along the stages of introduction, growth, maturity and decline. Given the competitive environment of the innovation/diffusion process in the industry, Utterback and Abernathy (1975) developed a model of the dynamics of innovation - the innovation life cycle model to describe the process of innovation and the degree of technological change. The innovation life cycle also provides a basis for technological forecasting. According to the study of the innovation process by Fisher and Pry (1971), they argued that, when a new innovation reaches about 5 per cent penetration of the potential application market, it provides a reasonable base for forecasting the speed and ultimate penetration achievable. Such intention model explores the relationship between attitude and behavioural intention is the Technology Acceptance Model (TAM). The TAM assumes that the key determinant of behavioural intentions is depends on a person's beliefs about their own ability to use a piece of technology and their subjective evaluation of the usefulness of that technology (Bruner \& Kumar, 2005; Hernandez, Jimenez, \& Martin, 2009; Morgan \& Veloutsou, 2011; Palvia, 2009; Pavlou, Liang, \& Xue, 2007). Scholars seldom use the consumer's point of view to combine with the intention model to discuss factors that affected behavioural intention to use a new technology in past researches (Legris, Ingham, \& Collerette, 2003; Szajna, 1996). Because the Fintech Service is an innovative high-tech product, using Fintech Service as a study subject and TAM to investigate consumers who use Fintech Service or have the potential intention to use Fintech Service to explore whether consumer attitudes concerning Fintech Service has significant effects on the behavioural intention to use Fintech Service is becoming an important issue.

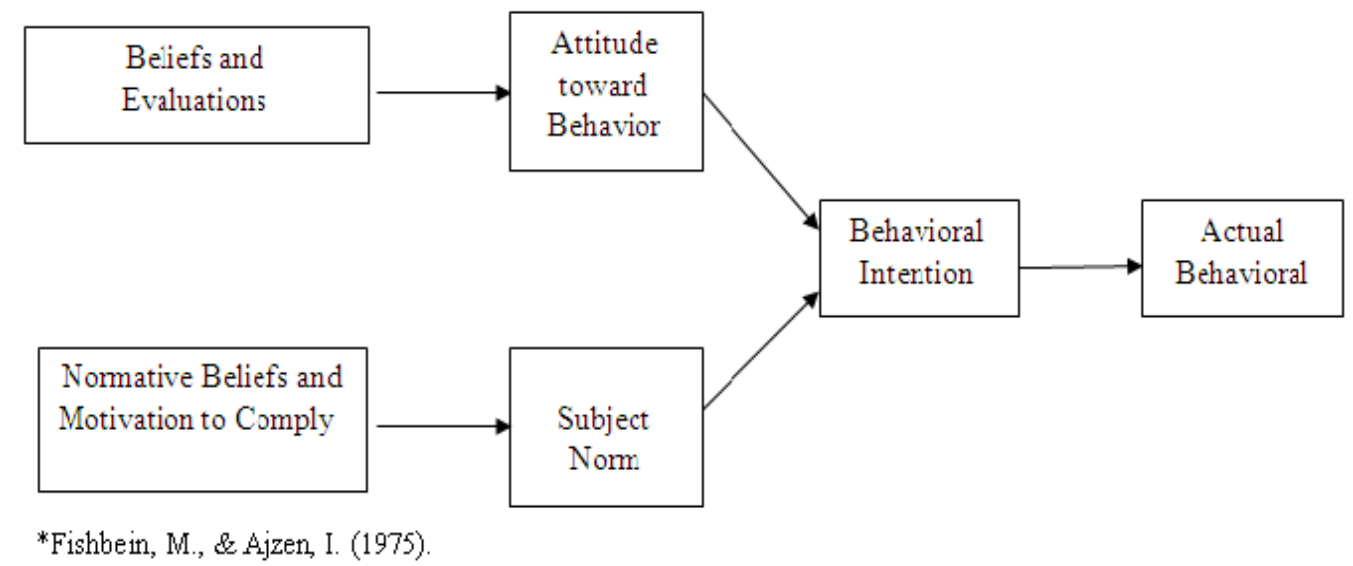

Figure 1 Theorv of Reasoned Action (TRA) 
This study used brand and service trust as an antecedent for the control variable of attitude to discuss whether brand and service trust significantly affect consumer attitudes toward using Fintech Service and whether consumer attitudes toward using Fintech Service affect consumer behavioural intention to use Fintech Service

\subsection{The concepts of TAM}

1. Attitude: the positive or negative feelings or evaluations generated when an individual uses new technologies. When a person has a higher positive attitude toward using new technology, the behavioural intention will be comparatively higher. It is determined by both perceived usefulness and perceived ease of use.

a) the perceived usefulness is "the degree to which a person believes that using a particular system will enhance his or her job performance". On the other hand, when a user believes that the new technology is useful, the user will have a positive attitude toward this new technology.

b) the perceived ease of use is "the degree to which a person believes that using a new technology is free from effort". When a new technology is perceived by users to be easy to use, and requires less labor and time, then the new technology is more likely to be accepted by users.

2. Behavioural intentions: the degree of a person's willingness to use a new technology.

3. External variables: The factors indirectly affect behaviours, such as the personal variables of users, system characteristics, and environmental variables. Many scholars have focused on factors that affect the use of new technologies, including relative advantage, ease of use, compatibility, trial ability, visibility, result demonstrability, image, and voluntariness (Moore \& Benbasat. 1991; Svendsen, Johnsen, Sørensen, \& Vitters ø. 2013).

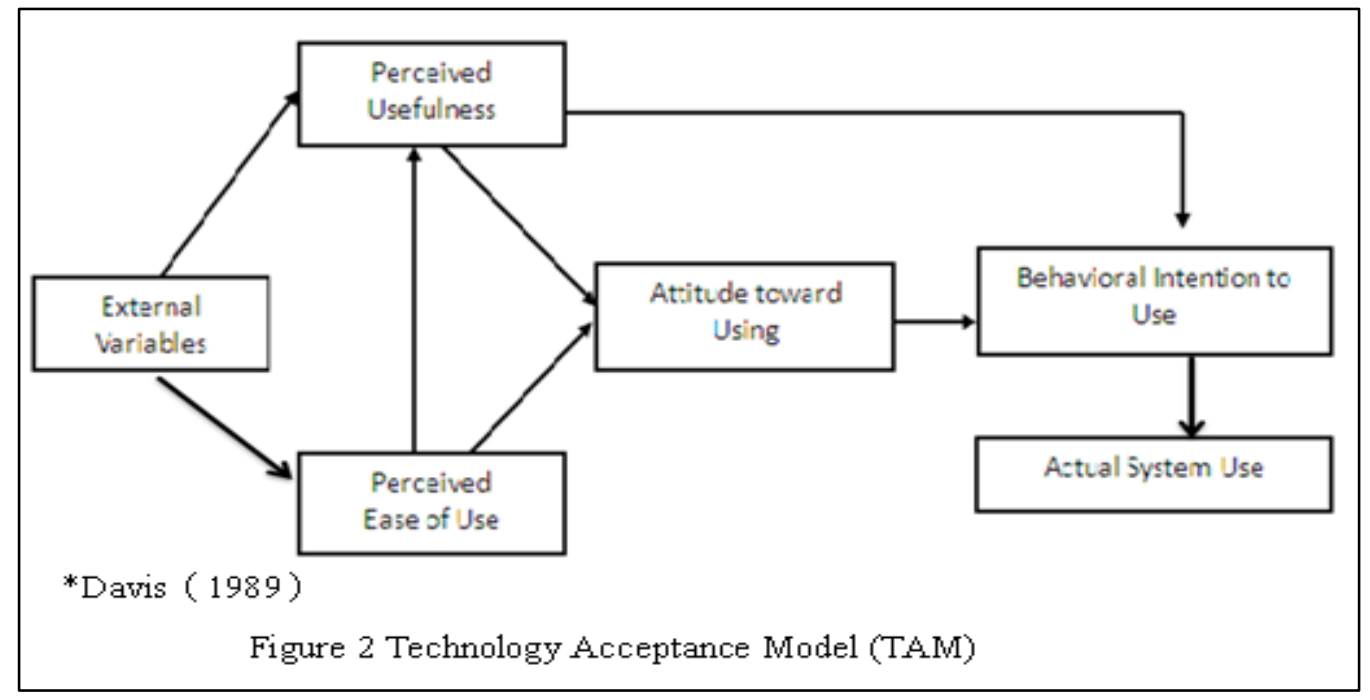

The perceived usefulness and perceived ease of use would affect the behaviour of using new technologies, and would be affected by the external variables included individual characteristics, system characteristics, and organizational support (Igbaria, Guimaraes, \& Davis, 1995). This study collected the past relevant research literatures that affect the use of new technology factors, and found that indeed there are many scholars adapted TAM as the main theoretical framework and developed many empirical bases.

\subsubsection{The Influence of Brand and Service Trust on Attitude toward Using Fintech Service}

Trust is based on the relationships between people and people, people and objects, or people and things. The three elements of trust are benevolence, honesty, and competence (Doney \& Cannon, 1997). Trust is perceived credibility and benevolence (Singh \& Sirdeshmukh, 2000), involves specific beliefs in ability, benevolence, and integrity and is willing to depend on 
another party. Trust has been conceptualized as a confidence (Pavlou, 2003; Pavlou \& Gefen, 2004). A trustor believes a trustee will meet the trustor's needs, will be confidence in the intentions or actions of a person or a group (Carnevale \& Wechsler, 1992). The trusting party expects the party to be trusted will complete a particular action without monitoring or controlling (Mayer, Davis \& Schoorman, 1995). A party to be trusted will not use deception to obtain benefits and trustworthiness. Moreover, Lee and Turban (2001) assumed that trust is a belief, expectancy, or feeling about certain items, certain antecedents will increase or maintain the degree of trust that will affect the trust of both parties on the transaction. A person will not take any unexpected action that would result in negative outcomes or risks for the trading partners (Anderson and Narus, 1990). Because of the Fintech Service are still not popular; sometimes the users of Fintech Service need to search for the services through website. When the quality and relevant functions of the product are unclear, the brand can help consumers make a selection (Ratnasingam, 2003). Enterprises can take advantage of the reputation of their brand value, such as its stability, long history, and trustworthiness to overcome a consumer's trust question. The brand and service reputation of enterprises have positive effects on trustworthiness in consumers (Veloutsou, 2007). Heijden, Verhagen, and Creemers (2003) proposed that cognition of trust and experiences when using new technology will directly affect a consumer's purchasing attitude. When the brand and service trust of consumers is higher, the attitude toward purchasing is more positive. When consumers believe that the information provided by enterprises is honest, consumers will adopt a positive attitude toward this enterprise. Hence, the definition of "brand and service trust" in this study is "the degree of influence that company reputation, website quality, and system security have on the behavioural intention of consumers to use Fintech Service".

\subsubsection{The Effect of Perceived Usefulness and Perceived Ease of Use on Attitude toward Using Fintech Service}

"Attitude" is determined by both perceived usefulness and perceived ease of use. To promote a user's willingness to use a new technology, it is necessary to let potential users believe that the new technology is easy to use and that they can benefit from using it (Chau \& Hu, 2002; Davis, 1986, 1989) "Perceived usefulness" referred to that the potential users considered the new technology is useful on job performance and they can get benefit in the future. (Moon \& Kim, 2001; Venkatesh \& Davis, 2000). "Perceived ease of use" referred to the degree of the potential users considered the new technology is easy to use (Moon \& Kim, 2001; Venkatesh \& Davis, 2000). The "usefulness" and "ease of use" of technology acceptance factors both have positive effects on "attitude". Users believe that the benefits provided by Fintech Service are useful (e.g., they can rapidly complete their work tasks) and are easy to use (e.g., they can get started without another's guidance), which is helpful for increasing users' attitude toward Fintech Service. If consumers believe that Fintech Service are more useful for their work or are easy to use, their attitude toward using Fintech Service is also higher. Thus, the perceived usefulness and ease of use of Fintech Service are cognitive factors for consumers to accept Fintech Service.

\subsubsection{The Effect of Attitude on Behavioural Intention to Use Fintech Service}

Most previous studies showed that attitude has a significant positive impact to the behavioural intention of individual (Venkatesh \& Davis, 2000). The behavioural intention of potential users was decided subjective norms; and the behavioural intention of existing users is depend on their behaviour and attitude. A consumer's "attitude toward using" and "willingness of using" Fintech Service should have a significantly positive relationship. When consumers sense positive evaluations, they will believe that using Fintech Service is a good experience and increase their willingness of using them. In addition, when consumers believe that using Fintech Service is a convenient and practical tool, they would recommend using them, the other 
consumers' attitude toward using Fintech Service will be affected and increased. Hence, the attitude has a positive effect relationship with behavioural intention to use.

\subsubsection{Research Hypotheses}

In this study, TAM is used as the foundation, and referenced relevant literature to construct a holistic conceptual framework. Figure 3 depicts the hypothesized relations examined in this investigation.

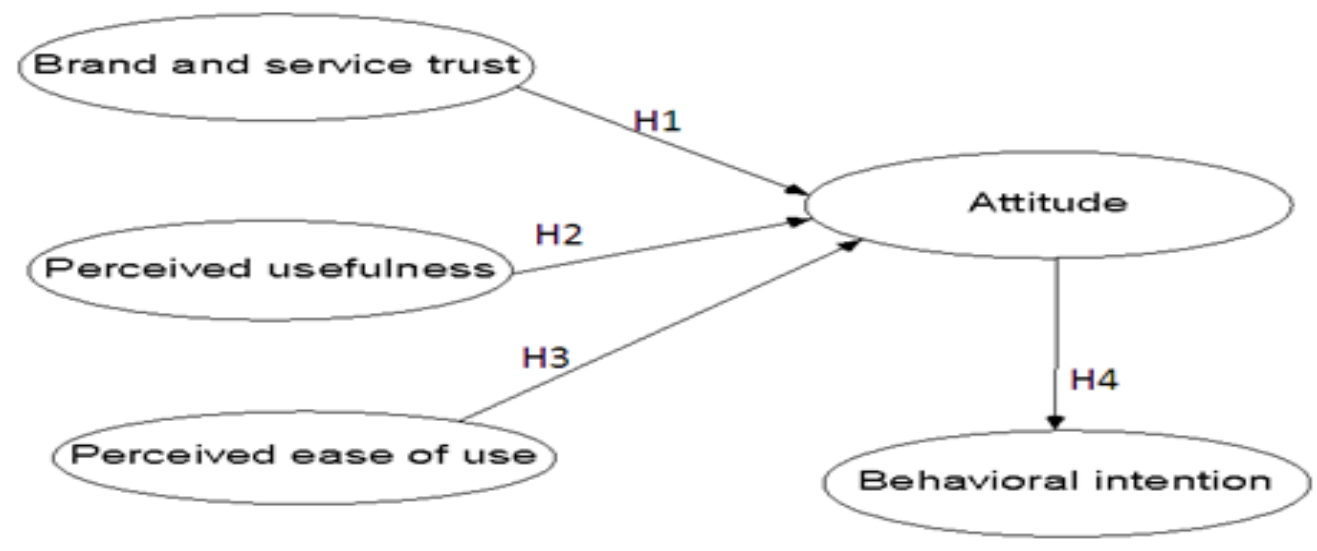

Figure 3 Hypothesized Mode1

H1: Brand and service trust has a significant positive effect on a consumer's attitude toward using Fintech Service

H2: Perceived usefulness will have a significant positive effect on a consumer's attitudes toward using Fintech Service.

H3: Perceived ease of use will have a significant positive effect on a consumer's attitudes toward using Fintech Service

H4: Consumer's attitude toward using Fintech Service has a significant positive effect on behavioural intention to use Fintech Service

\section{METHODOLOGY}

\subsection{Data Collection}

This study distributed 250 copies of the questionnaire and used the data of the questionnaire to perform reliability analysis. The values of Cronbach $\alpha$ coefficient of the 5 dimensions were all larger than the standard value of 0.7. Therefore, this study used the questionnaire as the formal questionnaire. Using convenience sampling, this study collected the questionnaire data from the engineers of manufacturing industries in Industrial Park. 500 copies of the questionnaire were distributed, and 440 valid copies were collected, the percentage of valid questionnaires was $88 \%$.3.2. Measures The questionnaire included sections comprising questions about brand and service trust, perceived usefulness, perceived ease of use, attitude, behavioural intention, and finally demographic characteristics. Response to the items was measured on four-point Likert-type scales anchored by "strongly disagree" (1) and "strongly agree" (5).

\subsection{Brand and Service Trust}

The operational definition of brand and service trust is "The degree of effect on consumer trust toward enterprises that provide Fintech Service by brand and system security" (Gefen \& Straub, 2003; Pavlou, 2003; Singh \& Sirdeshmukh, 2000); the list of attributes of brand and service trust was selected from a developed scale from prior research (Gefen \& Straub, 2003). A factor analysis on the samples resulted in the number of items has been reduced from 7 to 3 . 
Perceived usefulness The operational definition of perceived usefulness is "Consumer belief as to the degree of helpfulness of using Fintech Service" (Davis, 1989). The list of attributes of perceived usefulness was selected from the developed scale by Davis (1989). The factor analysis on the samples resulted in the number of items has has been reduced from 6 to 4. 3.2.3. Perceived ease of use The operational definition of perceived ease of use is "Consumers believe that the use of Fintech Service is easy and does not require too much effort to learn" (Davis, 1989). The list of attributes of perceived ease of use was also selected from a developed scale by Davis (1989) and Saadé (2007). The factor analysis on the samples resulted in the number of items has been reduced from 6 to 4. 3.2.4. Attitude The operational definition of Attitude is "The degree of a consumer's positive and negative evaluations on using Fintech Service" (Ajzen, 2002; Halilovic \& Cicic, 2011). The list of attributes of perceived ease of use was selected from a developed scale by (Ajzen, 2002; Halilovic \& Cicic, 2011). The factor analysis on the samples resulted in the number of items has been reduced from 5 to 3. 3.2.5. Behavioural intention The operational definition of behavioural intention is "The subjective judgment of consumers on the possibility of willingness to use Fintech Service in the future" (Ajzen, 2002). The list of attributes of perceived ease of use was selected from a developed scale by (Ajzen, 2002). The factor analysis on the samples resulted in the number of items has been reduced from 5 to 2. 3.3. Procedures The proposed model were tested with a LISREL (version 8.51) procedure of structural equation modeling (SEM), and the maximum likelihood method of estimation and the two-stage testing process were adopted. Prior to LISREL analysis, the multiitem constructs were tested by exploratory factor analyzing (EFA) each set of scale items using the principal axis with varimax method provided in SPSS (version 12.0). The underlying factors derived from EFA were represented as indicators to measure a construct. This procedure may help to reduce multi-collinearity or error variance correlations among indicators in the confirmatory factor analysis of the measurement model followed by the structural model. A number of additional goodness of fit measures is used to assess model fit. These include rootmean-square error of approximation (RMSEA), incremental fit index (IFI), comparative fit index (CFI), normed fit index (NFI), and relative fix index (RFI) (Jöreskog \& Sörbom 1996). Acceptable model fits are indicated by GFI and CFI values exceeding .90 and RMSEA values below .08 (Browne \& Cudeck 1993).

\section{RESULT}

The sample demographics of this study were illustrated in Table 3. The multi-item constructs in Table 4 were tested by exploratory factor analyzing (EFA) each set of scale items using the principal axis with varimax method provided in SPSS. The measure scale composite reliabilities (Cronbach's alpha) ranged from 0.73 (Attitude toward using) to 0.87 (Behavioural intention to use). Cortina (1993) has indicated that scales possessing a reduced number of items, 0.60 and above may be acceptable.

\begin{tabular}{|c|c|c|c|}
\hline \multicolumn{4}{|c|}{ Table 3 Demographic information of the participants Characteristic $N=220$} \\
\hline Variable & Description & Frequency & Percentage $(\%)$ \\
\hline Gender & Male & 85 & 38.63 \\
\hline \multicolumn{2}{|c|}{ Female } & 135 & 61.36 \\
\hline Marital Status & Married & 123 & 55.68 \\
\hline \multicolumn{2}{|c|}{ Single } & 97 & 44.31 \\
\hline Age & $21-30$ & 114 & 43.86 \\
\hline \multicolumn{2}{|c|}{$31-40$} & 66 & 30.00 \\
\hline \multicolumn{2}{|c|}{$41-50$} & 22 & 10.22 \\
\hline \multicolumn{2}{|l|}{ Over 50} & 18 & 7.95 \\
\hline Education & Below Senior High School & 37 & 16.81 \\
\hline \multicolumn{2}{|c|}{ College } & 139 & 63.19 \\
\hline \multicolumn{2}{|c|}{ Above college } & 44 & 20.00 \\
\hline
\end{tabular}


Measurement Models: Confirmatory Factor Analysis Measurement models for all the constructs to be used for the subsequent structural equation modeling were created, and goodness of fit of these models was tested using confirmatory factor analysis (CFA). The measured indicator variables depicted with squared boxes in Figure 4 represent respondents' mean scores of the items, along with their raw scores of the questionnaire items for brand and service trust, perceived usefulness, perceived ease of use, attitude and behavioural intention.

Analysis of Overall Model Fit Table showed indices test results of the CFA measurement model. All the test indicators of this type met the testing standards, e.g., $\chi^{2} / d f$ was 1.96 and less than 3, and the RMSEA was 0.07 and less than 0.08. In addition, the GFI (goodness-of-fit index) was 0.82 , which was close to the testing standard of greater than 0.09. The RMR (root mean squared residual) value was 0.06 , which was slightly higher than the testing standard of 0.05 .

Table 4 Factor analysis results of all measurement items

\begin{tabular}{|c|c|c|c|c|c|}
\hline Factors & Mean & S.D. & $\begin{array}{l}\text { Factor } \\
\text { loading }\end{array}$ & $\alpha$ & Item label -Item description \\
\hline \multicolumn{3}{|c|}{ Brand and service trust (BS) } & \multicolumn{3}{|l|}{0.82} \\
\hline $\begin{array}{l}\text { Mean }=4.54 \\
\text { S.D. }=1.14\end{array}$ & \multicolumn{2}{|l|}{4.43} & 1.13 & 0.84 & $\begin{array}{l}\text { I have confidence in Fintech Service provided } \\
\text { by enterprises (BS3) }\end{array}$ \\
\hline \multicolumn{2}{|l|}{4.45} & 1.10 & \multicolumn{2}{|l|}{0.82} & $\begin{array}{l}\text { I believe the transaction process and results of } \\
\text { Fintech Service are correct (BS 4) }\end{array}$ \\
\hline \multicolumn{2}{|l|}{4.53} & 1.12 & \multicolumn{2}{|l|}{0.85} & $\begin{array}{l}\text { I believe the transaction system of Fintech } \\
\text { Service is secure (BS 7) }\end{array}$ \\
\hline \multicolumn{3}{|c|}{ Perceived usefulness (PU) } & \multicolumn{3}{|l|}{0.84} \\
\hline $\begin{array}{l}\text { Mean }=4.60 \\
\text { S.D. }=1.16\end{array}$ & \multicolumn{2}{|l|}{4.45} & 1.30 & 0.83 & $\begin{array}{l}\text { I think using Fintech Service can make reading } \\
\text { more efficient (PU 1) }\end{array}$ \\
\hline \multicolumn{2}{|l|}{4.31} & 1.28 & \multicolumn{2}{|l|}{0.80} & $\begin{array}{l}\text { I think using Fintech Service will not be limited } \\
\text { by time and location restriction, which is helpful } \\
\text { for me (PU 3) }\end{array}$ \\
\hline \multicolumn{2}{|l|}{4.56} & 1.13 & \multicolumn{2}{|l|}{0.85} & $\begin{array}{l}\text { I think using Fintech Service can make life more } \\
\text { convenient (PU 6) }\end{array}$ \\
\hline \multicolumn{2}{|l|}{4.33} & 1.20 & \multicolumn{2}{|l|}{0.82} & $\begin{array}{l}\text { I think I can rapidly obtain information using e } \\
\text { Fintech Service (PU8) }\end{array}$ \\
\hline \multicolumn{3}{|c|}{ Perceived ease of use (PEU) } & \multicolumn{3}{|r|}{ 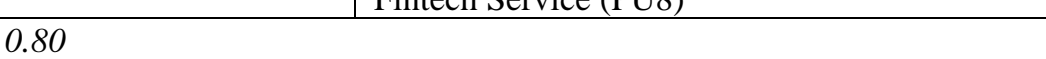 } \\
\hline $\begin{array}{l}\text { Mean }=4.40 \\
\text { S.D. }=1.22\end{array}$ & \multicolumn{2}{|c|}{4.59} & 1.22 & 0.84 & $\begin{array}{l}\text { I think it is easy to download application } \\
\text { programs from internet using Fintech Service } \\
\text { (PEU 1) }\end{array}$ \\
\hline \multicolumn{2}{|l|}{4.68} & 1.16 & \multicolumn{2}{|l|}{0.81} & $\begin{array}{l}\text { I think it is very easy to complete transactions } \\
\text { using Fintech Service (PEU 2) }\end{array}$ \\
\hline \multicolumn{2}{|l|}{4.57} & 1.11 & \multicolumn{2}{|l|}{0.78} & $\begin{array}{l}\text { I think it is easy to get started using Fintech } \\
\text { Service without reading the service manual } \\
\text { (PEU4) }\end{array}$ \\
\hline \multicolumn{2}{|l|}{4.36} & 1.20 & \multicolumn{2}{|l|}{0.78} & $\begin{array}{l}\text { I think it is easy to learning Fintech Service } \\
\text { without spend too much time (PEU 6) }\end{array}$ \\
\hline \multicolumn{3}{|c|}{ Attitude toward using (A) } & \multicolumn{3}{|l|}{0.75} \\
\hline $\begin{array}{l}\text { Mean }=4.59 \\
\text { S.D. }=1.18\end{array}$ & \multicolumn{2}{|l|}{4.83} & 1.13 & 0.83 & $\begin{array}{l}\text { I think it is very convenient to look up } \\
\text { information using Fintech Service anytime and } \\
\text { anywhere. (A 1) }\end{array}$ \\
\hline \multicolumn{2}{|l|}{4.04} & 1.10 & \multicolumn{2}{|l|}{0.83} & $\begin{array}{l}\text { I think using Fintech Service is a good idea. (A } \\
\text { 2) }\end{array}$ \\
\hline \multirow{2}{*}{\multicolumn{3}{|c|}{\begin{tabular}{l|l}
4.06 & 1.18 \\
Behavioural intention to use (BI)
\end{tabular}}} & \multicolumn{2}{|l|}{0.76} & I like the idea of using Fintech Service. (A 4) \\
\hline & & & 0.86 & & \\
\hline $\begin{array}{l}\text { Mean }=4.35 \\
\text { S.D. }=0.82\end{array}$ & \multicolumn{2}{|c|}{4.79} & 1.25 & 0.86 & $\begin{array}{l}\text { I want to use the services provided by Fintech } \\
\text { Service (BI1) }\end{array}$ \\
\hline 4.59 & & 1.28 & 0.86 & & $\begin{array}{l}\text { I want to use Fintech Service to connect } \\
\text { information (BI } 3\end{array}$ \\
\hline
\end{tabular}


On the other hand, all the test indicators of this type met or were close to the testing standard value of greater than 0.09; for example, the NFI (normed fit index) was 0.84, the CFI (comparative fit index) was 0.91, the IFI (incremental fit index) value was 0.91, and the RFI (relative fit index) value was 0.82 . Therefore, the overall model fit tests mostly attained the testing standard, which had an excellent fit.

Table 5 Hypothesis Relationship Path Test Result

\begin{tabular}{|c|l|c|c|c|}
\hline Hypothesis & \multicolumn{1}{|c|}{ Path } & $\begin{array}{c}\text { Path } \\
\text { value }\end{array}$ & C.R./t & E/N \\
\hline H1 & brand and service trust $\rightarrow$ attitude toward using & 0.42 & $3.07^{* *}$ & Supported \\
\hline H2 & perceived usefulness $\rightarrow$ attitude toward using & 0.84 & $4.66^{* * *}$ & Supported \\
\hline H3 & perceived ease of use $\rightarrow$ attitude toward using & 0.31 & $2.15^{* * *}$ & Supported \\
\hline H4 & $\begin{array}{l}\text { attitude toward using } \rightarrow \text { behavioural intention } \\
\text { to use }\end{array}$ & 0.86 & $9.08^{* * *}$ & Supported \\
\hline
\end{tabular}

$*: P<0.05, * *: P<0.01, * * *: P<0.001)$

Hypothesis Testing of Each Variable Path From the empirical analysis and testing results, a path diagram of the relationships among the dimensions of brand and service trust, perceived usefulness, perceived ease of use, attitude toward using, and behavioural intention to use in this study was constructed and is presented in Figure. The conclusions of the hypothesis testing performed in this study were showed in Table

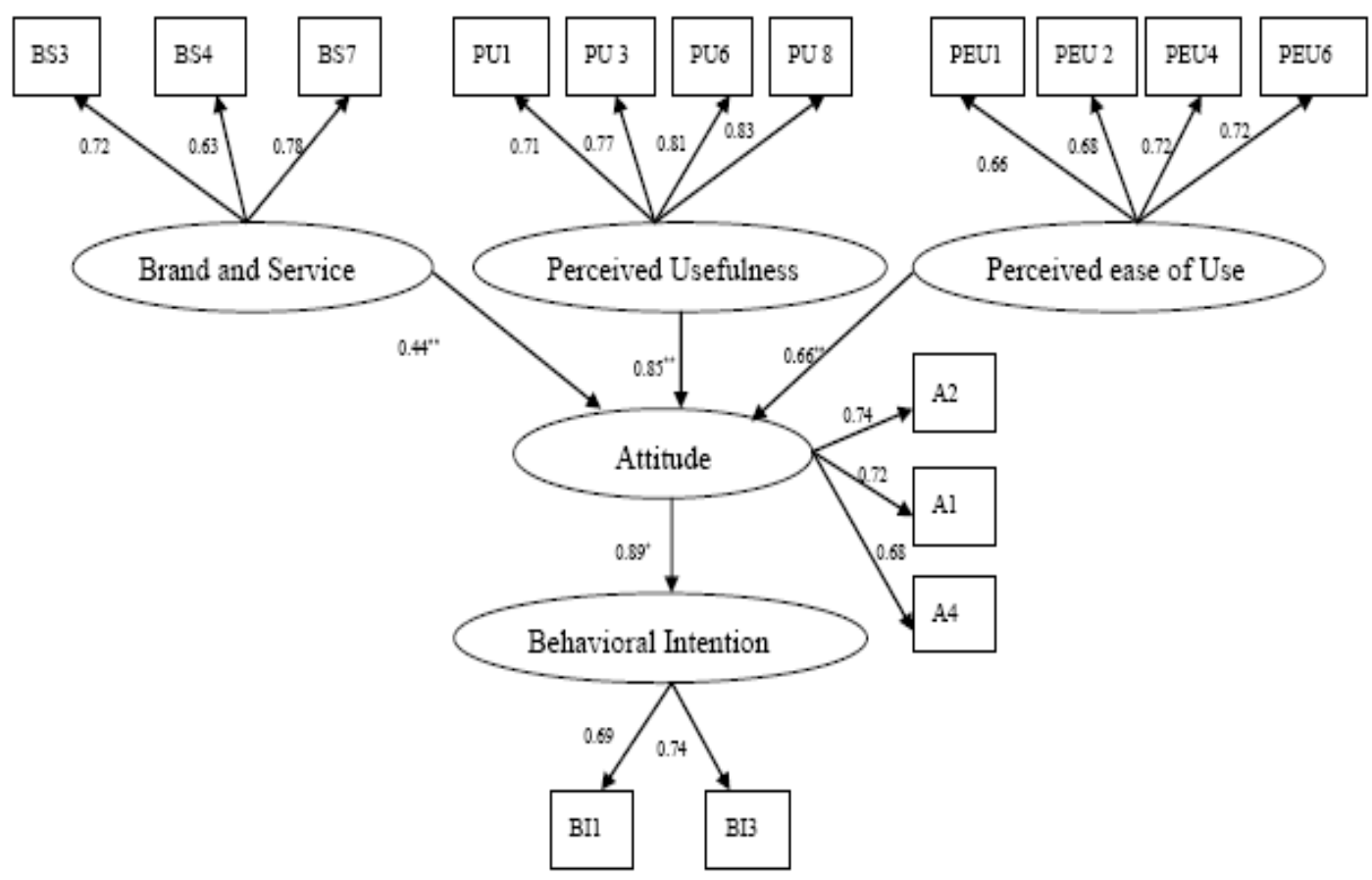

Figure 4 Measurement models tested using Confirmatory Factor Analysis (CFA) 
Table 6 Model fit-indices

\begin{tabular}{|c|c|c|c|c|c|c|c|c|c|}
\hline \multicolumn{2}{|c|}{ Model } & \multicolumn{10}{c|}{ Criteria } \\
\hline \multicolumn{2}{|c|}{$\chi^{2 / \mathrm{df}}$} & P-value & RMSEA & GFI & RMR & NFI & CFI & IFI & RFI \\
\hline \multicolumn{2}{|c|}{} & $>0.05$ & $<0.08$ & $>0.9$ & $\begin{array}{c}<0.0 \\
5\end{array}$ & $>0.9$ & $>.9$ & $>0.9$ & $>0.9$ \\
\hline Measurement & 1.96 & 0.000 & 0.07 & 0.82 & 0.06 & 0.84 & 0.91 & 0.91 & 0.82 \\
\hline
\end{tabular}

Hypothesis 1: Brand and service trust has a significant positive effect on a customer's attitude toward using Fintech Service. The path coefficient of brand and service trust on attitude toward using Fintech Service was 0.42 and the t value was 3.07, which was greater than the standard value of 1.96 and attained the significant level; therefore, Hypothesis 1 is valid. This result means that if consumers have higher brand and service trust toward using Fintech Service, then their attitude toward using Fintech Service will be more positive.

Hypothesis 2: Perceived usefulness has a significant positive effect on a customer's attitude toward using Fintech Service. The path coefficient of perceived usefulness on attitude toward using Fintech Service was 0.84, and the t value was 4.66, which was greater than the standard value of 1.96 and attained the significant level; therefore, Hypothesis 2 is valid.

This result means that if the consumer's view regarding how helpful it is to use Fintech Service is more positive, then their general attitude toward using Fintech Service is more positive.

The path coefficient of perceived ease of use on attitude toward using 3D Printing was 0.31 , and the $\mathrm{t}$ value was 2.15 , which was less than the standard value of 1.96 and attained the significant level; therefore, Hypothesis 3 is valid.

This result means that the degree of ease of learning and using Fintech Service for consumers will affect consumer's attitude toward using the product.

The path coefficient of attitude toward using on behavioural intention to use Fintech Service was 0.86 , and the $t$ value was 9.08, which was greater than the standard value of 1.96 and attained the significant level; therefore, Hypothesis 4 is valid.

This result means that if the level of a consumer's positive and negative evaluation of Fintech Service is higher, then the consumer's behavioural intention of using will be higher.

\section{CONCLUSION}

\subsection{Research Result}

1. If customers are satisfied with the Fintech Service that provided by enterprises (brand/company reputation/trust), such as the transaction processes and results are correct, or the transaction system is safe and secure, then customers will have high levels of brand and service trust in Fintech Service.

2. If the Fintech Service enables customers to obtain relevant information efficiently, conveniently, and quickly on enterprises or perform transactions in real-time and free of time and location restrictions, then the customer's positive attitude toward using Fintech Service will increase.

3. If the Fintech Services are ease-of-using, the processes of operation are friendliness, and ease of downloading application program, this technology will affect customer's attitude toward using Fintech Service.

4. The degree of positive and negative evaluation of customers in using Fintech Service is the most important factor that affects whether customers will use Fintech Service. 


\subsection{Research Implications}

Based on the results of this study, the major findings have significant managerial implication. This finding reveals the importance of understanding the behavioural intention toward using Fintech Service. First of all, the exploratory factor analysis for consumer behaviour showed that the acceptance of new technology 5 domains (brand and service trust, perceived usefulness, perceived ease of use, attitude toward using, and behavioural intentions to use) When evaluating people's acceptance of new technology experiences domain, they may think of positive experiential aspects, such as social psychological interaction within their clients or the enterprises, the cost control of the products for the manufacturing industries, or the process convenience of the new technology, and conflict-related attributes included in this study with the quality of the new technology. Be being able to identify setting performance, the enterprises managers may be able to alter customers' experiences in order to maximize their attitude toward using Fintech Service and then increase behavioural intention toward using Fintech Service. By understanding the relationships between the technology services provided, and how they affect customers, the enterprises managers should be better equipped all to satisfy and to retain clients. For the success of marketing new technology, thus, it is suggested that the marketers should focus on building the relationship between customers about the enterprise's brand and service trust. Not only let customers perceive usefulness of the new technology, but also perceive ease of use of the new technology; because they can be fundamental factors increasing satisfaction with setting performance and activity. Expect to affect the customer's attitude toward using, and behavioural intentions to use, so that the new technology can be accepted by customers. In the competitive market, servicing industries and products services must be linked complementary closely to gain the market share. On the other hand, a key factor to enhance the development of economic is continuing make advances in technology; the continuous technological progress is the main component in increasing added value for servicing industries; and the new technologies can make new investments profitable. Continuous technological progress must depend on continued research and development. Therefore, the upgrading of servicing industrial and developing of economic should focus on research and development to build the brand.

\subsection{Limitation and Future Research}

In order to compare the acceptance of Fintech Service for different industries, it might be possible to induct other industries as the sampling frame. This study is based on the servicing industry; suggest future research can be extended sample objects to other industries, and to learn more about different areas of consumer acceptance of Fintech Service approach. For improving an understanding of consumer's behaviour, further research should focus on the examination of the effects of other factors such as social norms and situational variables moderated the relationship between attitude and behavioural intention, the servicing costs significantly influence the acceptance of Fintech Service, and the product of Fintech Service will influence their attitude. In other words, future studies on quality-satisfaction relationship should consider other variables that may be included as alternative or additional antecedents to behavioural or control these effects.

Finally, there are other issues associated with this study's limitations that should be discussed to offer suggestions for future research. The proposed model was tested in the acceptance of Fintech Service. Generalization of this model must be examined using various settings. In conclusion, longitudinal analysis would clarify our understanding of the mechanisms influencing the link between satisfaction and loyalty in general. 


\section{REFERENCES}

[1] Alt, R., \& Puschmann, T. (2012). The rise of customer-oriented banking - electronic markets are paving the way for change in the financial industry. Electronic Markets, 22(4), 203-2015.

[2] Anderson, J. C., \& Narus, J. A. (1990). A model of distributor firm and manufacturer firm working partnerships. Journal of Marketing, 54(1): 42-58.

[3] Ajzen, I. (2002). Perceived Behavioural Control, Self-Efficacy, Locus of Control, and the Theory of Planned Behaviour. Journal of Applied Social Psychology, 32(4): 665-683.

[4] Browne, M. W., \& Cudeck, R. (1993). Alternative ways of assessing model fit. In K.A. Bollen and J. S. Long (Eds.), Testing structural equation models. Newbury Park, CA: Sage: 136-162.

[5] Bruner G. C., \& Kumar, A.(2005). Explaining consumer acceptance of handheld Internet devices. Journal of Business Research, 58(5):553- 558.

[6] Carnevale, D. G., \& Wechsler, B. (1992). Trust in the public sector. Administration \& Society, 23(4): 471-494.

[7] Chau, P. Y. K., \& Hu, P. J. H. (2002). Investigating Healthcare Professionals' Decisions to Accept Telemedicine Technology: An Empirical Test of Competing Theories. Information \& management, 39(4): 297-311.

[8] Chen, L., Gillenson, M. \& Sherrell, D. (2002). Enticing On-line Consumers: An Extended Technology Perspective. Information and Management, 39(8): 705-719.

[9] Cheung, R., \& Vogel, D. (2013). Predicting user acceptance of collaborative technologies: An extension of the technology acceptance model for e-learning. Computers \& Education, 63, 160 175

[10] Cortina, J. M. (1993). What is coefficient alpha? An examination of theory and applications. Journal of Applied Psychology, 78(1): 98-104.

[11] Davis, F.D. (1986). A Technology Acceptance Model for Empirically Testing New End-User Information System: Theory and Results, Doctoral Dissertation, Sloan School of Management, Massachusetts Institute of Technology, Cambridge, MA.

[12] Davis, F. D. (1989). Perceived Usefulness, Perceived Ease of Use, and User Acceptance of Information Technology. MIS Quarterly, 13(3): 319-340.

[13] Davis, F.D., Bagozzi, R.P., \& Warshaw, P.R. (1989). User Acceptance of Computer Technology: A Comparison of Two Theoretical Models. Management Science, 35(8): 9821002.

[14] Doney, P. M., \& Joseph, P. C. (1997). An examination of the nature of trust in buyer-seller relationships. Journal of Marketing, 61(2): 35-51.

[15] Eltayeb, M., \& Dawson, M. (2016). Understanding User's Acceptance of Personal Cloud Computing: Using the Technology Acceptance Model. Information Technology: New Generations, 448, 3-12.

[16] Fishbein, M., \& Ajzen, I. (1975). Belief, Attitude, Intention, and Behaviour: An Introduction to Theory and Research, Vermont South: ARRB Group Limited.

[17] Gefen, D., \& Straub, D. W. (2003). Managing User Trust in B2C e-Service. E-Service Journal, 2(2): 7-24.

[18] Halilovic, S., \& Cicic, M. (2011). Antecedents of information systems user behaviour: extended expectation-confirmation model. Behaviour \& Information Technology, 32(4): 359-370.

[19] Heijden, H., Verhagen, T., \& Creemers, M. (2003). Understanding online purchase intentions: contributions from technology and trust perspectives. European Journal of Information Systems, 12: 41-48. 
[20] Hernandez, B., Jimenez,J., \& Martín, M. J. (2009). Adoption vs acceptance of e-commerce: two different decisions, European Journal of Marketing, 43(9/10): 1232 -1245.

[21] Igbaria, M., Guimaraes, T., \& Davis, G. B. (1995). Testing the Determinants of Microcomputer Usage Via a Structural Equation Model. Journal of Management Information Systems, 11(4): 87-114.

[22] Jöreskog, K. G.; \& Sörbom, D. 1996. LISREL 8: Structural equation modeling with the SIMPLIS command language. Chicago, IL: Scientific software International.

[23] Kim, Y., Park, Y. J., Choi, J, \& Yeon, J. (2015). An Empirical Study on the Adoption of "Fintech" Service: Focused on Mobile Payment Services. Advanced Science and Technology Letters, 114, 136-140

[24] Lee, M.K., \& Turban, E. (2011). A Trust Model for Consumer Internet Shopping. International Journal of Electronic Commerce, 6(1): 75-91.

[25] Legris, P., Ingham, J., \& Collerette, P. (2003). Why do people use information technology? A critical review of the technology acceptance model. Information \& Management, 40(3): 191204.

[26] Mayer, R. C., Davis, J. H., \& Schoorman, F. D. (1995). An integration model of organizational trust. Academy of Management Review, 20(3): 709-734.

[27] McAuley, D. (2014). What is FinTech? Wharton FinTech.

[28] Moon, J. W., \& Kim, Y. G. (2001). Extending the TAM for a World-Wide-Web Context. Information and Management, 38(4): 217-230.

[29] Moore, G. C. \& Benbasat, I. (1991). Development of an Instrument to Measure the Perceptions of Adopting an Information Technology Innovation. Information Systems Research, 2(3): 192222.

[30] Morgan, A., \& Veloutsou, C. (2011). Beyond technology acceptance: Brand relationships and online brand experience. Journal of Business Research, 66(1):21-27.

[31] Palvia P. (2009). The role of trust in e-commerce relational exchange: a unified model. Information \& Management, 46(4):213- 220.

[32] Pavlou, P. A. (2003). Consumer Acceptance of Electronic Commerce: Integrating Trust and Risk with the Technology Acceptance Model. International Journal of Electronic Commerce, 7(3): 101-134.

[33] Pavlou, P. A., \& Gefen, D. (2004). Building effective online marketplaces with institution-based trust. Information Systems Research, 15(1): 37-59.

[34] Pavlou, P. A., Liang, H., \& Xue, Y. (2007). Understanding and mitigating uncertainty in online exchange relationships: a principal-agent perspective. MIS Quarterly, 31(1): 105-136.

[35] Ratnasingam, P. (2003). Inter-organizational trust in business-to-business: A case study in customs clearance. Internet of Global Information Management, 11(1): 1-19.

[36] Saadé, R. G. (2007). Dimensions of perceived usefulness: toward enhanced assessment. Decision Sciences Journal of Innovative Education, 5(2): 289-310.

[37] Singh,J. , \& Sirdeshmukh, D. (2000). Agency and Trust Mechanisms in Consumer Satisfaction and Loyalty Judgments. Journal of Academy of Marketing Science, 28(1): 150-167.

[38] Svendsen, G.B., Johnsen, J. K., Sørensen, L. A., \& Vitters $\varnothing$, J. (2013). Personality and technology acceptance: the influence of personality factors on the core constructs of the Technology Acceptance Model. Behaviour \& Information Technology, 32(4): 323 - 334.

[39] Szajna, B. (1996). Empirical Evaluation of the Revised Technology Acceptance Model. Management Science, 42(1): 85-92. 
[40] The Directorate General of Budget, Accounting and Statistics (DGBAS) of Executive Yuan, R.O.C. Taiwan. 2015. http://eng.dgbas.gov.tw/mp.asp?mp=2.

[41] Veloutsou. C. (2007). Identifying the dimensions of the product-brand and consumer relationship. Journal of Marketing Management, 23(1/2): 7- 26.

[42] Venkatesh, V. \& Davis, F. D. (2000). A Theoretical Extension of the Technology Acceptance Model: Four Longitudinal Field Studies, Management Science, 46(2): 186-204.

[43] Yousafzai, S. Y., Foxall, G. R., \& Pallister, J. G. (2010). Explaining Internet Banking Behaviour: Theory of Reasoned Action, Theory of Planned Behaviour, or Technology Acceptance Model? Journal of Applied Social Psychology, 40(5),1172-1202.

[44] Yu, J., Ha, I., Choi, M., \& Rho, J. (2005). Extending the TAM for a T-Commerce. Information and Management, 42(7): 965-976.

[45] Li-Min Chuang1, Chun-Chu Liu2 \& Hsiao-Kuang Kao, (ISSN: 2225-7225), The Adoption of Fintech Service: TAM perspective 